\title{
New Vistas in the Molecular Chemistry of Thorium: Low Oxidation State Complexes
}

DOI:

10.1039/C6DT01111J

\section{Document Version}

Accepted author manuscript

Link to publication record in Manchester Research Explorer

\section{Citation for published version (APA):}

Ortu, F., Formanuik, A., Innes, J. R., \& Mills, D. (2016). New Vistas in the Molecular Chemistry of Thorium: Low Oxidation State Complexes. Dalton Transactions, 45(18), 7537-7549 . https://doi.org/10.1039/C6DT01111J

\section{Published in:}

Dalton Transactions

\section{Citing this paper}

Please note that where the full-text provided on Manchester Research Explorer is the Author Accepted Manuscript or Proof version this may differ from the final Published version. If citing, it is advised that you check and use the publisher's definitive version.

\section{General rights}

Copyright and moral rights for the publications made accessible in the Research Explorer are retained by the authors and/or other copyright owners and it is a condition of accessing publications that users recognise and abide by the legal requirements associated with these rights.

\section{Takedown policy}

If you believe that this document breaches copyright please refer to the University of Manchester's Takedown Procedures [http://man.ac.uk/04Y6Bo] or contact uml.scholarlycommunications@manchester.ac.uk providing relevant details, so we can investigate your claim.

\section{OPEN ACCESS}




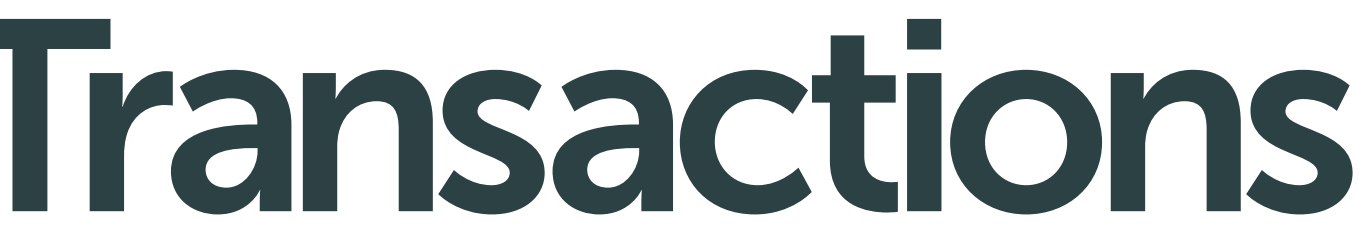

\section{Accepted Manuscript}

This article can be cited before page numbers have been issued, to do this please use: F. Ortu, A. Formanuik, J. R. Innes and D. P. Mills, Dalton Trans., 2016, DOI: 10.1039/C6DT01111J.

\section{Dalton Transactions}

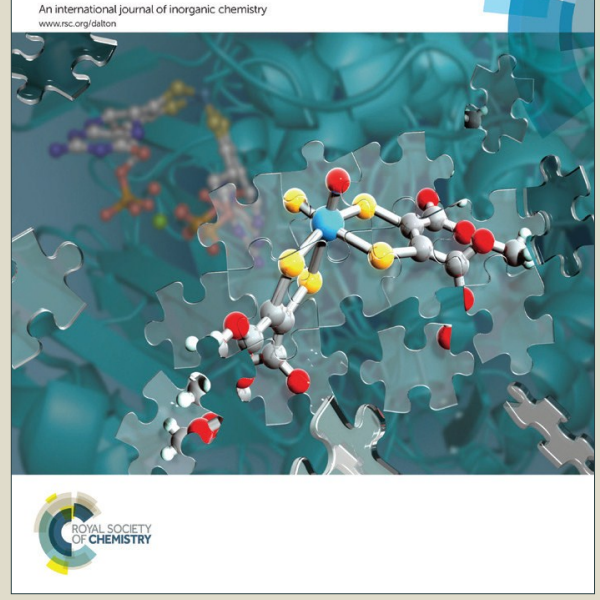

This is an Accepted Manuscript, which has been through the Royal Society of Chemistry peer review process and has been accepted for publication.

Accepted Manuscripts are published online shortly after acceptance, before technical editing, formatting and proof reading. Using this free service, authors can make their results available to the community, in citable form, before we publish the edited article. We will replace this Accepted Manuscript with the edited and formatted Advance Article as soon as it is available.

You can find more information about Accepted Manuscripts in the Information for Authors.

Please note that technical editing may introduce minor changes to the text and/or graphics, which may alter content. The journal's standard Terms \& Conditions and the Ethical guidelines still apply. In no event shall the Royal Society of Chemistry be held responsible for any errors or omissions in this Accepted Manuscript or any consequences arising from the use of any information it contains. 


\title{
New Vistas in the Molecular Chemistry of Thorium: Low Oxidation State Complexes
}

Fabrizio Ortu, Alasdair Formanuik, James R. Innes and David P. Mills* View Article Online
DOI: 10.1039/C6DT01111J School of Chemistry, The University of Manchester, Oxford Road, Manchester M13 9PL, UK. *david.mills@manchester.ac.uk

\begin{abstract}
Although the molecular chemistry of thorium is dominated by the +4 oxidation state accounts of Th(III) complexes have continued to increase in frequency since the first structurally characterised example was reported thirty years ago. The isolation of the first Th(II) complexes in 2015 and exciting recent $\mathrm{Th}(\mathrm{III})$ and $\mathrm{Th}(\mathrm{II})$ reactivity studies both indicate that this long-neglected area is set to undergo a rapid expansion in research activity over the next decade, as previously seen since the turn of the millennium for analogous $U(I I I)$ small molecule activation chemistry. In this perspective article, we review synthetic routes to $\mathrm{Th}(\mathrm{III})$ and $\mathrm{Th}(\mathrm{II})$ complexes and summarise their distinctive physical properties. We provide a near-chronological discussion of these systems, focusing on structurally characterised examples, and cover complementary theoretical studies that rationalise electronic structures. All reactivity studies of Th(III) and Th(II) complexes that have been reported to date are described in detail.
\end{abstract}

\section{Introduction}

Prodigious attention has been given in recent years to the chemistry of the actinides (An), with one of the main driving forces being the application of early to mid-Ans, specifically uranium and plutonium, in nuclear energy and weapons development. Thorium, the first element in the An series, has been mooted as a potential nuclear fuel to complement ubiquitous uranium based reactors in the foreseeable future; firstly by the implementation of MSFR (Molten Salt Fast Reactor) technology, and secondly by adaptation of existing PWRs (Pressurised Water Reactors) to include MOX (Mixed-OXide) Fuels. ${ }^{1,2}$ Economic interest in pursuing these outcomes is stimulated by the high abundance of thorium in the Earth's crust compared to uranium (9.6 and $2.7 \mathrm{ppm}$ respectively), ${ }^{3}$ combined with the high natural isotopic abundance of Th-232 (100\%) compared to 
that of U-235 $(0.72 \%)$, eliminating the requirement for isotopic enrichment and therefore creating less waste. ${ }^{4}$

Overcoming some of the issues in the generation of nuclear energy has inevitably led to a better understanding of the fundamental properties of the Ans, in particular uranium due to its relatively low radiological hazard. Numerous discoveries in non-aqueous An chemistry have been made over the past 60 years, driven by the increased level of control given by performing chemistry under strict anaerobic conditions. ${ }^{5}$ Fundamental results obtained from these studies, for example gauging the extent of covalency in An-ligand bonds, can be transferred to industrially relevant systems. Whilst polarised covalent An-ligand bonding interactions are predominantly ionic, small differences in covalency are induced by the choice of An, metal oxidation state and coordinated ligands. Such variations are expressed experimentally in internuclear separations in nuclear fuel cycles. ${ }^{6,7}$

As the An series is traversed, the $5 f$ orbital becomes less chemically accessible, thereby stabilising the +3 oxidation state and leading to lanthanide- (Ln) like behaviour for late Ans. ${ }^{5 b}$ In contrast early An exhibit a range of oxidation states, but their chemistry tends to be predominated by higher states. For example, uranium tends to exhibit the +6 oxidation state in the presence of oxygen, ${ }^{5}$ but in non-aqueous conditions the +3 oxidation state is readily accessible, as demonstrated by the facile syntheses of $\mathrm{U}(\mathrm{III})$ starting materials. ${ }^{8}$ Rapid recent developments in low oxidation state uranium chemistry have led to landmark advances, such as the discovery of intrinsic single molecule magnet behaviour ${ }^{9}$ and remarkable small molecule activation chemistry ${ }^{10}$ of $\mathrm{U}$ (III) complexes. Furthermore, the facile $2 \mathrm{e}^{-}$oxidation of $\mathrm{U}$ (III) complexes has also generated interest for their potential applications in precious metal-like catalytic processes. ${ }^{11}$ The interesting reactivity of $\mathrm{U}(\mathrm{III})$ complexes stems from their ability to undergo selective oxidation processes, with concomitant reduction of the target molecule or substrate. This has been widely reported in the literature and further discussion will not be covered in this work. ${ }^{5 a}$

Thorium chemistry is dominated by the +4 oxidation state, due to both an absence of useful low oxidation state starting materials, and having to overcome a relatively large standard reduction potential from $\mathrm{Th}(\mathrm{IV})$ precursors to access lower oxidation states $\left[\mathrm{E}^{\ominus} \mathrm{Th}(\mathrm{IV}) \rightarrow \operatorname{Th}(\mathrm{III})-3.7 \mathrm{~V}\right.$, cf. $\mathrm{U}(\mathrm{IV}) \rightarrow \mathrm{U}(\mathrm{III})-0.6 \mathrm{~V}] .^{12}$ Considering the fascinating reactivity displayed by $\mathrm{U}(\mathrm{III})$ complexes, it is 
surprising that $\mathrm{Th}(\mathrm{III})$ chemistry lags so far behind, as the standard reduction potential data

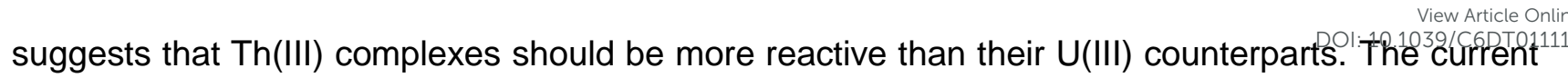
dearth of Th(III) chemistry can be attributed to a deficiency in synthetic routes to Th(III) complexes, and analysis of the physical properties of these systems is equally underdeveloped. Even more challenging is the stabilisation of molecular early Ans(II) species, particularly for thorium which features a remarkably disfavoured reduction potential $\left[\mathrm{E}^{\ominus} \operatorname{Th}(\mathrm{III}) \rightarrow \operatorname{Th}(\mathrm{II})-4.9 \mathrm{~V}\right] .^{12}$ Herein we review the chemistry of thorium in low oxidation states over the last 40 years, including synthesis, studies of electronic structures and examples of reactivity studies of both $\mathrm{Th}$ (III) and $\mathrm{Th}$ (II) complexes.

\section{Synthesis and properties of Th(III) complexes}

\subsection{General considerations}

The inherent instability of thorium in oxidation states lower than +4 was thoroughly challenged over the second part of the twentieth century. The first reports on the existence of trivalent thorium date back to the 1950s and 1960s, based on the identification of $\mathrm{Th}$ (III) and $\mathrm{Th}$ (II) subhalides and oxides. $^{13}$ The precise formulation of some of these species is uncertain but it is noteworthy that Corbett reported the synthesis of $\mathrm{Thl}_{2}$ by the reduction of $\mathrm{Thl}_{4}$ with Th metal. ${ }^{13 \mathrm{c}}$ Elemental thorium is unique amongst the Ans as it exhibits a $6 d^{2} 7 s^{2}$ valence electronic configuration, indicating that the $6 \mathrm{~d}$ manifold is lower in energy than the $5 \mathrm{f}$ orbitals at the start of the An series. In the early Ans, calculations of An-ligand bonding require virtual $5 \mathrm{f}$ and $6 \mathrm{~d}$ orbitals to be taken into account, together with the semi-core $6 s$ and $6 \mathrm{p}$. However, there is increasing evidence that the An orbital contribution to An-ligand bonding interactions in such systems are dominated by the $6 \mathrm{~d}$ orbitals. ${ }^{6,14}$

In complexes of the general formula $\left[\mathrm{An}(\mathrm{Cp})_{3}\right]\left(\mathrm{Cp}=\right.$ cyclopentadienyl, $\left.\mathrm{C}_{5} \mathrm{H}_{5}{ }^{-}\right)$, which exhibit approximate $C_{3 v}$ symmetry, the symmetry-combined ligand e orbitals preferentially interact with the actinide $6 \mathrm{~d}$ orbitals of $e$ symmetry. Therefore, the $6 \mathrm{~d}$ orbitals are responsible for the main An-ligand covalent interactions in these systems, whilst the $5 f$ orbitals, with the exception of the $a_{2}$ combination, give rise to essentially non-bonding orbitals (Figure 1). ${ }^{14 a}$ Noticeably, there is only a very weak interaction of the $a_{1}$ ligand orbital combination with the An orbitals in $\left[\mathrm{An}(\mathrm{Cp})_{3}\right]$, leaving an essentially pure An $6 d_{z}{ }^{2}$ orbital. ${ }^{14 a}$ As already stated, at the start of the An series this orbital lies 
below the $5 f$ manifold, leading to the prediction that thorium should have a $6 d^{1}$ ground state (see below). ${ }^{14 a, b}$ Kaltsoyannis and co-workers have shown that orbital mixing increases across the early ${ }^{\text {View Article Online }}$ An series in $\left[\mathrm{An}(\mathrm{Cp})_{3}\right]$ systems due to the contraction of the $5 f$ orbitals, which become closer in energy to the frontier orbitals of the $\mathrm{Cp}$ ligands. ${ }^{15}$ This phenomenon does not mean that there is an increase in An-ligand covalency for heavier Ans; in fact the ionic character of the bonding increases across the series. ${ }^{5 b}$

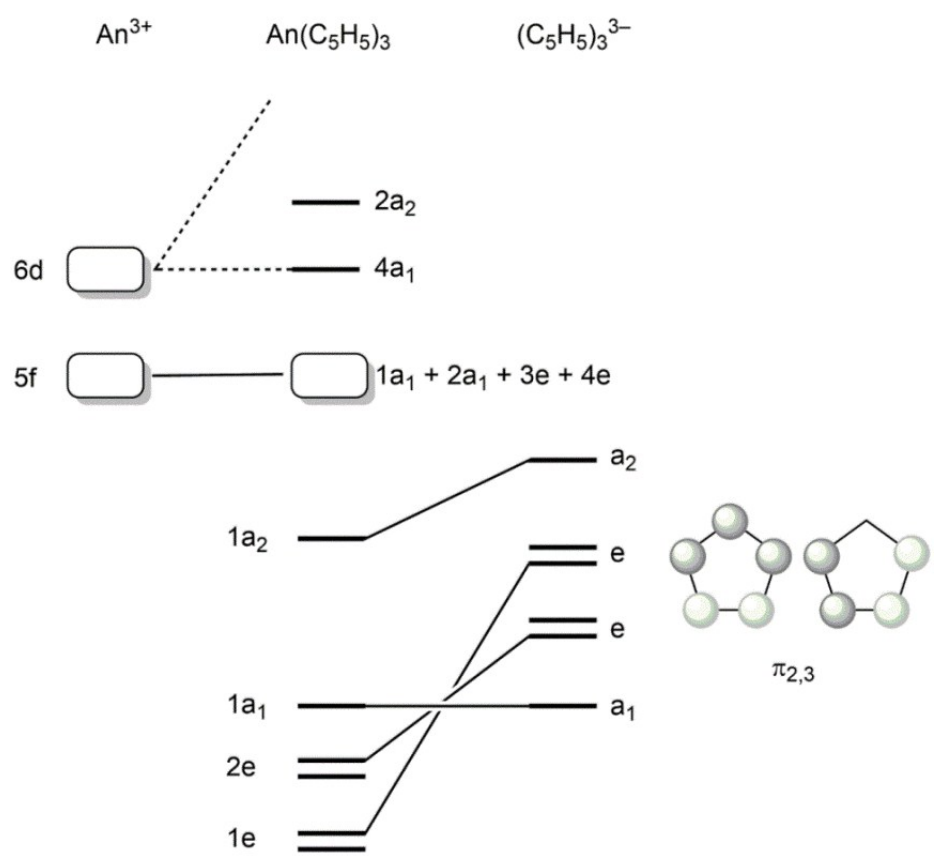

Figure 1. Qualitative $\mathrm{MO}$ diagram of $\left[\mathrm{An}(\mathrm{Cp})_{3}\right]$ complexes in approximate $C_{3 \mathrm{v}}$ symmetry, extracted from Bursten and co-workers. ${ }^{14 a}$

From the synthetic point of view the isolation of molecular Th(III) complexes has been a major challenge, and progress has been relatively slow since the first Th(III) species were reported in the 1970s. ${ }^{16} \mathrm{Th}(\mathrm{III})$ complexes have only been isolated with the rigorous exclusion of oxygen and moisture, and strong reducing agents are required to overcome the considerable $\mathrm{Th}(\mathrm{IV}) \rightarrow \mathrm{Th}(\mathrm{III})$ reduction potential $\left[\mathrm{E}^{\ominus}-3.7 \mathrm{~V}\right]^{12}$ as there are no useful $\mathrm{Th}(\mathrm{III})$ starting materials for molecular chemists. ${ }^{13}$ As such the choice of coordinated ligands is vital to both saturate the thorium coordination sphere and reduce the magnitude of this potential. All structurally characterised Th(III) complexes to date are stabilised by relatively soft anionic donor ligands with delocalised $\pi$-systems such as substituted $\mathrm{Cp}$. It is noteworthy that there has been an isolated 
report of Th(III) being detected in aqueous solution; ${ }^{17}$ however these results were refuted shortly afterwards. $^{18}$

\subsection{Cyclopentadienyl complexes}

Cyclopentadienyl ligands have found most applicability to date for the stabilisation of $\mathrm{Th}(\mathrm{III})$ complexes as they occupy approximately three coordination sites; therefore, three $\mathrm{Cp}$ ligands almost saturate the metal coordination sphere. In 1974 Baumgärtner and co-workers reported the reduction of a heteroleptic Th(IV) Cp complex, $\left[\mathrm{Th}(\mathrm{Cp})_{3}(\mathrm{Cl})\right]$, with sodium/naphthalene in THF to give a violet solid, which was formulated as $\left[\mathrm{Th}(\mathrm{Cp})_{3}\right]$ (1) from elemental analysis, FTIR spectroscopy and magnetic data (Scheme 1). ${ }^{16}$ No structural authentication of 1 was presented due to its low solubility in hydrocarbon solvents. It is possible that the lack of bulky groups on the $\mathrm{Cp}$ rings leads to oligomerisation in the solid state, as has been observed in analogous ionic $\left[\mathrm{Ln}(\mathrm{Cp})_{3}\right]$ systems, ${ }^{19}$ though this was not confirmed.

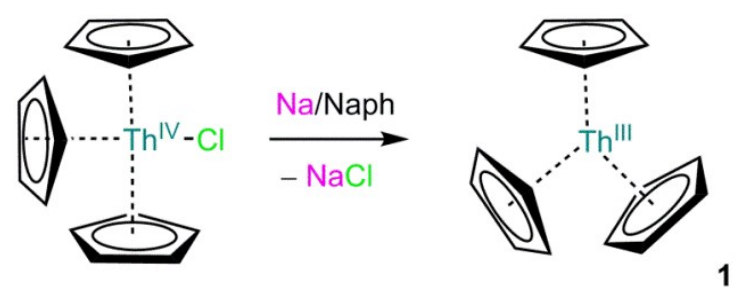

Scheme 1. Synthesis of $\left[\mathrm{Th}(\mathrm{Cp})_{3}\right](\mathbf{1})$ via reduction of $\left[\mathrm{Th}(\mathrm{Cp})_{3} \mathrm{Cl}\right]$ with sodium/naphthalene. ${ }^{16}$

Alternative synthetic routes to Th(III) species, avoiding alkali metals, were explored by Marks and co-workers a few years later. The thermolysis of $\left[\operatorname{Th}(\mathrm{Cp})_{3}(\mathrm{R})\right]\left(\mathrm{R}={ }^{i} \mathrm{Pr},{ }^{n} \mathrm{Bu}\right)$ in toluene at $170{ }^{\circ} \mathrm{C}$ for 9 days gave the Th(IV) complex $\left[\mathrm{Th}(\mathrm{Cp})_{2}\left(\mu-\eta^{1}: \eta^{5}-\mathrm{C}_{5} \mathrm{H}_{4}\right)\right]_{2}$, which was identified by mass spectrometry and elemental analysis. ${ }^{20}$ The reaction was postulated to proceed by $\mathrm{Cp}$ proton abstraction and the elimination of $\mathrm{RH}$, with $\beta$-hydride elimination pathways discounted through several control experiments. In a follow-up study, solutions of $\left[\mathrm{Th}\left(\mathrm{C}_{5} \mathrm{H}_{4} \mathrm{R}\right)_{3}\left({ }^{i} \mathrm{Pr}\right)\right]\left(\mathrm{R}=\mathrm{H}, \mathrm{CH}_{3}\right)$ in benzene at $4{ }^{\circ} \mathrm{C}$ were irradiated with a UV lamp to give the dark green $\mathrm{Th}(\mathrm{III})$ complexes, $\left[\mathrm{Th}\left(\mathrm{C}_{5} \mathrm{H}_{4} \mathrm{R}\right)_{3}\right]\left(\mathbf{1}, \mathrm{R}=\mathrm{H} ; \mathbf{2}, \mathrm{R}=\mathrm{CH}_{3}\right)$, with propane and propene generated in approximately equal quantities (synthesis of 2 only illustrated in Scheme 2 for brevity). ${ }^{21}$ Under photolytic conditions $\beta$ - 
hydride elimination is favoured to give propene and Th(IV) hydride intermediates, $\left[T h\left(\mathrm{C}_{5} \mathrm{H}_{4} R\right)_{3}(\mathrm{H})\right]$,

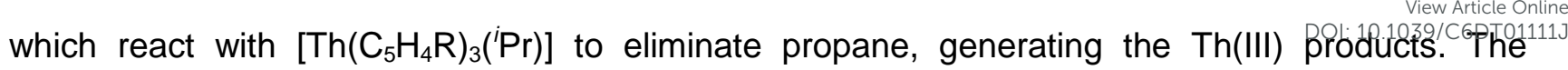
divergence in reaction pathways was attributed to photochemical rearrangement of coordinated $\mathrm{Cp}$ to $\eta^{1}$ - and $\eta^{3}$ - modes, opening up the Th coordination sphere and generating the vacant coordination site that is necessary for $\beta$-hydride elimination to take place. Complexes $\mathbf{1}$ and $\mathbf{2}$ were characterised by elemental analysis, mass spectrometry and Raman, FTIR and electronic spectroscopy of solid samples, with the low solubility of these complexes precluding their characterization by solution phase NMR spectroscopy.
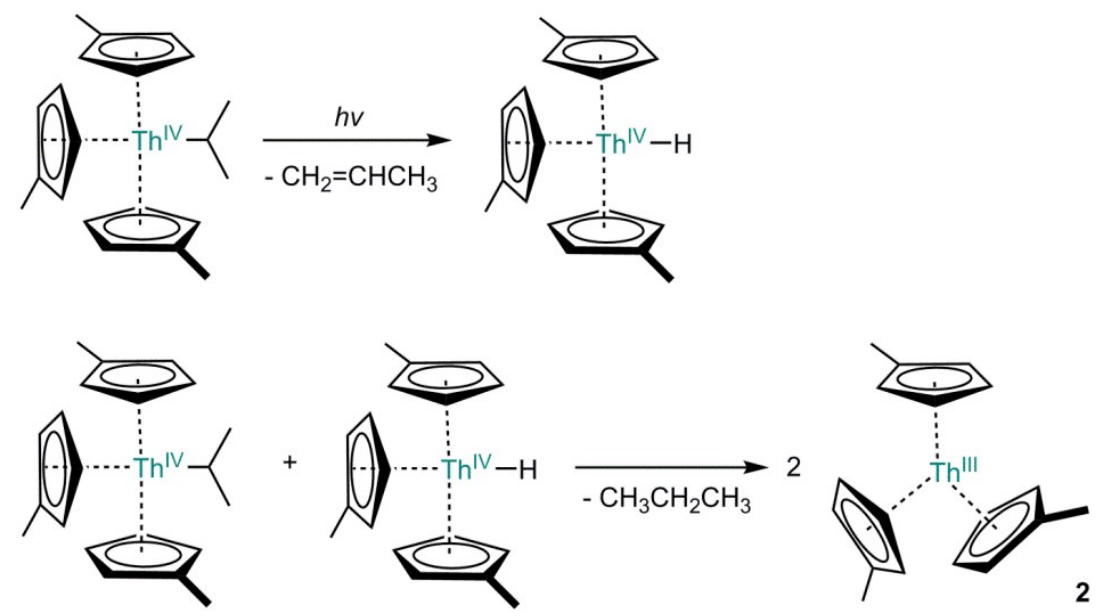

Scheme 2. Synthesis of $\left[\mathrm{Th}\left(\mathrm{C}_{5} \mathrm{H}_{4} \mathrm{Me}\right)_{3}\right](2)$ by photolysis of $\left[\mathrm{Th}(\mathrm{Cp})_{3}\left({ }^{i} \mathrm{Pr}\right)\right]{ }^{21}$

Marks and co-workers later tested the generality of these methods to generate An(III) $\mathrm{Cp}$ complexes by comprehensively investigating the photolysis of a wide range of heteroleptic $\mathrm{Th}(\mathrm{IV})$ and U(IV) Cp alkyls; namely $\left[T h\left(\mathrm{C}_{5} \mathrm{E}_{5}\right)_{3}(\mathrm{R})\right]\left(\mathrm{E}=\mathrm{H}, \mathrm{D} ; \mathrm{R}=\mathrm{CH}_{3}, i-\mathrm{C}_{3} \mathrm{H}_{7}, n-\mathrm{C}_{4} \mathrm{H}_{9}\right),\left[\mathrm{U}\left(\mathrm{C}_{5} \mathrm{E}_{5}\right)_{3}(\mathrm{R})\right](\mathrm{E}=$ $\mathrm{H}, \mathrm{R}=\mathrm{CH}_{3}, i-\mathrm{C}_{3} \mathrm{H}_{7}, n-\mathrm{C}_{4} \mathrm{H}_{9}$, sec $\left.-\mathrm{C}_{4} \mathrm{H}_{9} ; \mathrm{E}=\mathrm{D}, \mathrm{R}=n-\mathrm{C}_{4} \mathrm{H}_{9}\right)$, and $\left[\mathrm{Th}\left(\mathrm{C}_{5} \mathrm{H}_{4} \mathrm{Me}\right)_{3}\left(n-\mathrm{C}_{4} \mathrm{H}_{9}\right)\right] \cdot{ }^{22} \mathrm{~A}$ considerable number of control experiments were carried out to confidently assign the various mechanisms in operation in these reactions, with $\beta$-hydride elimination to give $\mathbf{1}$ and $\mathbf{2}$ dominating for Th(IV) alkyl precursors except for $\mathrm{R}=\mathrm{CH}_{3}$, as would be expected. The magnetic susceptibility of 1, measured in this paper using Faraday techniques, was found to be highly temperature dependent $\left(0.404 \mu_{\mathrm{B}}, 298 \mathrm{~K} ; 0.10 \mu_{\mathrm{B}}, 4 \mathrm{~K}\right)$. Interestingly, the room temperature value is vastly different to that reported previously by Marks for the same compound $\left(2.10 \mu_{B}, 298 \mathrm{~K}\right),{ }^{21}$ but is 
almost identical to the value originally given by Baumgärtner and co-workers $\left(0.403 \mu_{\mathrm{B}}, 298 \mathrm{~K}\right){ }^{16}$

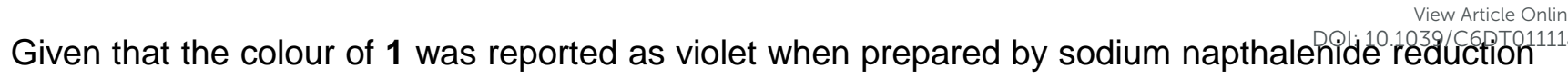
of $\left[\mathrm{Th}(\mathrm{Cp})_{3}(\mathrm{Cl})\right]$ and dark green when prepared by photolysis of $\left[\mathrm{Th}\left(\mathrm{C}_{5} \mathrm{H}_{4} \mathrm{R}\right)_{3}\left({ }^{i} \mathrm{Pr}\right)\right]$, discrepancies in these data are not surprising as solid state structures from the two synthetic routes could vary. Further to this, poor reproducibility of magnetic susceptibility data for different samples of the same Th(III) complex are a constant theme in the literature and are often attributed to varying amounts of diamagnetic impurities and differences in sample preparation (see below).

The novel $\mathrm{Th}(\mathrm{III})$ indenyl complex, $\left[\mathrm{Th}\left(\mathrm{C}_{9} \mathrm{H}_{7}\right)_{3}\right]$ (3), was prepared by photolysis of $\left[T h\left(\mathrm{C}_{9} \mathrm{H}_{7}\right)_{3}\left(n-\mathrm{C}_{4} \mathrm{H}_{9}\right)\right]$ in toluene as part of the same study by Marks (Scheme 3$) .{ }^{22}$ In this case the $\beta$ hydride elimination mechanism was discounted as only small traces of 1-butene were detected in the reaction mixture. The vast majority of gas evolved in the synthesis of 3 (>96\%) was identified as butane, and this was attributed to a photochemically-induced intramolecular hydrogen abstraction from an indenyl ligand taking place. Complex $\mathbf{3}$ is soluble in benzene and toluene; as such it was characterised by ${ }^{1} \mathrm{H}$ NMR spectroscopy [ $07.20(\mathrm{br}, 18 \mathrm{H}) ; 6.03(\mathrm{~d}, 1 \mathrm{H}) ; 5.82(\mathrm{~s}, 1 \mathrm{H})$ ] as well as elemental analysis and FTIR spectroscopy. It is noteworthy that the photolysis of [Th\{ $\left.\left.\mathrm{C}_{5} \mathrm{H}_{4}\left(\mathrm{C}_{2} \mathrm{H}_{5}\right)\right\}_{3}(\mathrm{R})\right]$ compounds to give dark green solids, possibly the Th(III) complex $\left[T h\left\{\mathrm{C}_{5} \mathrm{H}_{4}\left(\mathrm{C}_{2} \mathrm{H}_{5}\right)\right\}_{3}\right]$, was mentioned briefly in this paper. ${ }^{22}$ However, to the best of our knowledge supporting analytical data for this complex has not been published in the interim so this complex is not discussed further here.
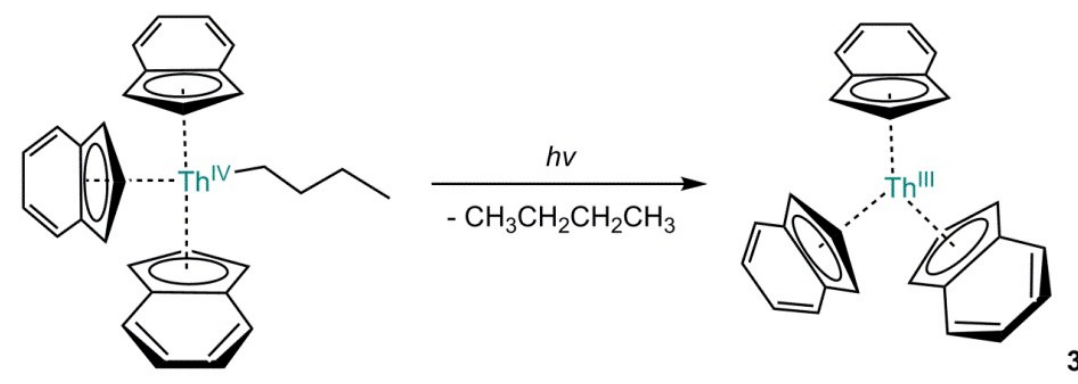

Scheme 3. Synthesis of $\left[\mathrm{Th}\left(\mathrm{C}_{9} \mathrm{H}_{7}\right)_{3}\right](3)$ by photolysis of $\left[\mathrm{Th}\left(\mathrm{C}_{9} \mathrm{H}_{7}\right)_{3}\left(n-\mathrm{C}_{4} \mathrm{H}_{9}\right){ }^{22}\right.$

The first structurally authenticated Th(III) complex, $\left[\mathrm{Th}(\mathrm{Cp})_{3}\right]\left(4, \mathrm{Cp}=\left\{\mathrm{C}_{5} \mathrm{H}_{3}\left(\mathrm{SiMe}_{3}\right)_{2}-1,3\right\}^{-}\right.$ ), was communicated by Lappert and co-workers in $1986 .{ }^{23}$ In the original synthetic procedure 
complex 4 was prepared by reduction of the dihalide precursor $\left[\mathrm{Th}(\mathrm{Cp} ")_{2}(\mathrm{Cl})_{2}\right]$ with a five-fold

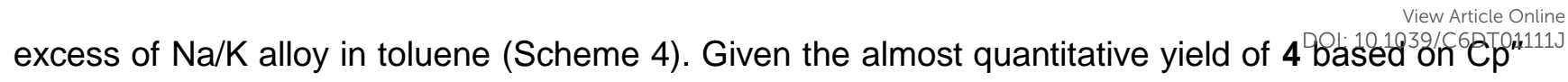
(85\%), a reductive disproportionation mechanism was postulated that invoked transient Th(III) and $\operatorname{Th}(\mathrm{II})$ intermediates, $\left[\mathrm{Th}(\mathrm{Cp})_{2}(\mathrm{Cl})\right]$ and $\left[\mathrm{Th}\left(\mathrm{Cp}^{\prime \prime}\right)_{2}\right]$, respectively. Although neither intermediate could be isolated, this pathway was preferred over ligand scrambling of $\left[\mathrm{Th}(\mathrm{Cp})_{2}(\mathrm{Cl})\right]$ based on the identification of metallic thorium in the reaction mixture and conjectures from comparable literature examples. In this paper complex $\mathbf{4}$ was characterised by single crystal XRD, ${ }^{1} \mathrm{H}$ NMR spectroscopy [ $\left.\delta 5.3\left(\mathrm{br}, w_{1 / 2}=900 \mathrm{~Hz}\right)\right]$ and elemental analysis (results not presented in this paper). Based on the solid state structure, paramagnetic NMR spectra and dark blue coloration, $\mathbf{4}$ was assigned a $5 f^{1}$ valence configuration, though this was later corrected following an EPR spectroscopy study (see below). In a follow-up paper the synthesis of 4 by Li reduction of $\left[\mathrm{Th}\left(\mathrm{Cp}^{\prime \prime}\right)_{3}(\mathrm{Cl})\right]$ in pentane was mentioned, but no yield was provided. ${ }^{24}$ Fifteen years after the original report of 4 improved synthetic routes were provided by Lappert in a full paper, with the reduction of $\left[\mathrm{Th}(\mathrm{Cp})_{3}(\mathrm{Cl})\right]$ by $\mathrm{Na} / \mathrm{K}$ in hexane with sonication providing the highest yield (92\%) (Scheme 4). ${ }^{25}$ Evans and coworkers later showed that the reduction of $\left[\mathrm{Th}\left(\mathrm{Cp}{ }^{\prime \prime}\right)_{3}(\mathrm{Br})\right]$ with $\mathrm{KC}_{8}$ in THF also gave an excellent yield of $4(89 \%)$ (Scheme 4$).{ }^{26}$ Lappert observed that when $\left[\mathrm{Th}(\mathrm{Cp} ")_{3}(\mathrm{Cl})\right]$ was treated with an excess of $\mathrm{Na} / \mathrm{K}$ in THF a dark green solution resulted. ${ }^{25}$ Given that the ${ }^{1} \mathrm{H}$ and ${ }^{13} \mathrm{C}\left\{{ }^{1} \mathrm{H}\right\} \mathrm{NMR}$ and EPR spectra of this reaction mixture were consistent with a diamagnetic product, it was postulated that $d^{2} \operatorname{Th}(\mathrm{II})$ complexes had formed such as $\left[\mathrm{K}(\mathrm{THF})_{n}\right]\left[\mathrm{Th}(\mathrm{Cp})_{3}\right]$ or $\left[\mathrm{Th}(\mathrm{Cp} ")_{2}(\mathrm{THF})_{n}\right]$. A structurally characterised Th(II) complex was later prepared by Evans and co-workers by the controlled reduction of 4 (see below). ${ }^{26}$

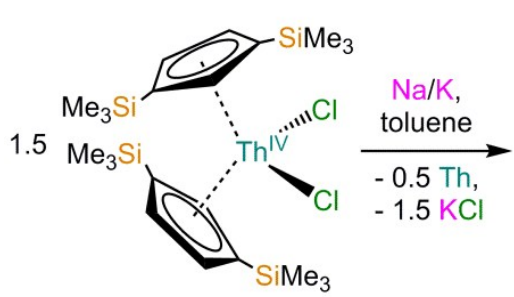

Scheme 4. Synthesis of $\left[\mathrm{Th}\left(\mathrm{Cp}^{\prime \prime}\right)_{3}\right](4)$ via i) reduction of $\left[\mathrm{Th}\left(\mathrm{Cp}^{\prime \prime}\right)_{2}(\mathrm{Cl})_{2}\right]$ with $\mathrm{Na} / \mathrm{K} ;{ }^{23,24}$ ii) reduction of $\left[\mathrm{Th}\left(\mathrm{Cp}^{\prime \prime}\right)_{3}(\mathrm{X})\right]$ with $\mathrm{Na} / \mathrm{K}(\mathrm{X}=\mathrm{Cl})^{25}$ or $\mathrm{KC}_{8}(\mathrm{X}=\mathrm{Br}){ }^{26}$ 


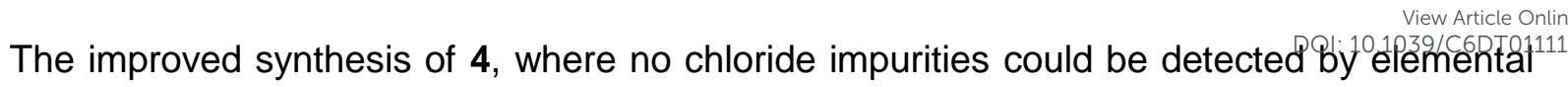
analysis, provided an opportunity for more characterisation data to be accumulated. ${ }^{25}$ The optical spectra of 4 were recorded at 298, 77 and $4 \mathrm{~K}$, with four relatively broad and intense absorptions indicating that a $6 d^{1}$ valence electron configuration is adopted, as $f-f$ transitions would exhibit absorption coefficients several orders of magnitude smaller than those observed. Brennan and Green were able to collect a UV photoelectron spectrum of 4 as it is volatile $<180{ }^{\circ} \mathrm{C}$ and $10^{-3}$ torr, showing a relatively low first ionisation potential $(4.87 \mathrm{eV})$ that is intermediate to the corresponding values for sodium and potassium. ${ }^{25}$ The magnetic susceptibility of samples of powdered 4 were measured from $5-300 \mathrm{~K}$ and all plots were reported to follow the Curie-Weiss law. However, $\mu_{\text {eff }}$ values obtained for different samples ranged from $0.4-1.56 \mu_{\mathrm{B}}$, which was attributed to variable amounts of diamagnetic impurities. The novel $\operatorname{Th}(\mathrm{III})$ complex $\left[\mathrm{Th}\left(\mathrm{Cp}^{\dagger \dagger}\right)_{3}\right] \quad\left(\mathbf{5}, \mathrm{Cp}^{\dagger \dagger}=\right.$ $\left.\left\{\mathrm{C}_{5} \mathrm{H}_{3}\left(\mathrm{SiMe}_{2}{ }^{t} \mathrm{Bu}\right)_{2}-1,3\right\}^{-}\right)$, synthesised by reduction of $\left[\mathrm{Th}\left(\mathrm{Cp}^{\dagger \dagger}\right)_{3}(\mathrm{Cl})\right]$ with $\mathrm{Na} / \mathrm{K}$ in toluene, was also reported by Lappert in the same paper (Scheme 5). ${ }^{25}$ The formulation of $\mathbf{5}$ was verified by single crystal XRD, elemental analysis and EPR spectroscopy.

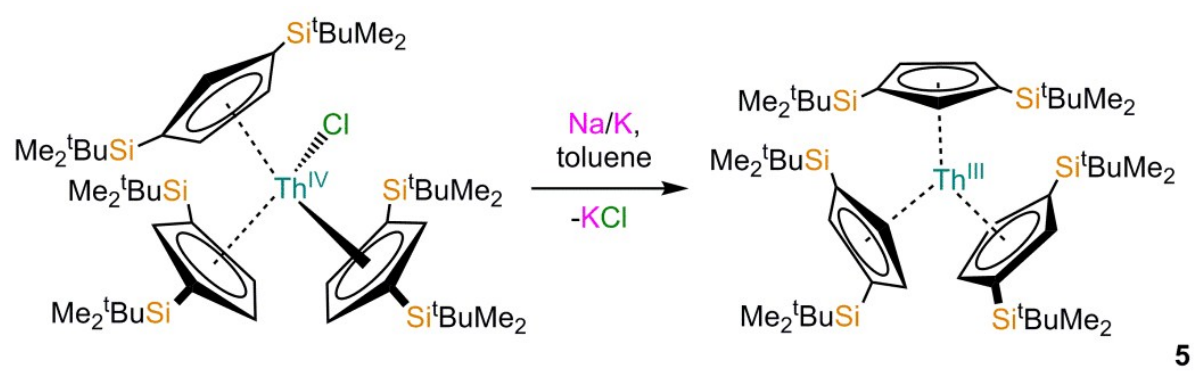

Scheme 5. Synthesis of $\left[\mathrm{Th}\left(\mathrm{Cp}^{\dagger \dagger}\right)_{3}\right](5)$ via reduction of $\left[\mathrm{Th}\left(\mathrm{Cp}^{\dagger \dagger}\right)_{3}(\mathrm{Cl})\right]$ with $\mathrm{Na} / \mathrm{K}^{25}$

Although the $\mathrm{Th}^{3+}$ free ion has a $5 \mathrm{f}^{1}$ ground state, Lappert, Edelstein and co-workers later established by EPR spectroscopy that $\mathbf{4}$ and $\mathbf{5}$ exhibit $6 \mathrm{~d}_{z}{ }^{1}$ valence configurations. ${ }^{25,27}$ Powder and solution samples of 4 (from 10-300 K) and 5 (at 100 and $300 \mathrm{~K}$ ) were measured at X-band, and these spectra were consistent with a ${ }^{2} A$ ' orbital singlet arising from splitting of $d$-orbitals in an approximate $D_{3 \mathrm{~h}}$ symmetry. The calculated $g$ values of $4\left(g_{\|}=1.994 ; g_{\perp}=1.896\right)$ were in good agreement with values obtained experimentally in both solution and powder samples for $\mathbf{4}$ and $\mathbf{5}$ 
(e.g. powdered 4: $g_{\|}=1.972 ; g_{\perp}=1.879 ; 5$ in methylcyclohexane: $\left.g_{\|}=1.976 ; g_{\perp}=1.894\right)$. Snijders

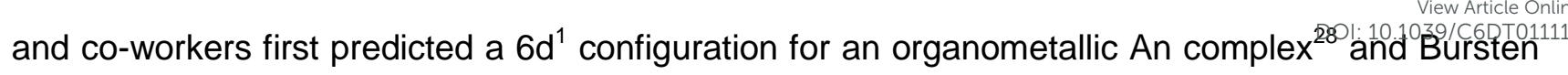
further corroborated these results with calculations, showing that the highest contribution to the $a_{1}{ }^{\prime}$ orbital in $\left[\mathrm{Th}(\mathrm{Cp})_{3}\right]$ arises from the $6 \mathrm{~d}_{\mathrm{z}}{ }^{2}$ orbital $(89 \%) .{ }^{14 a}$ The energy of the $6 \mathrm{~d}_{z}{ }^{2}$ orbital in these systems rises across the An series with a corresponding decrease in the $5 f$ manifold (Figure 2). The $6 \mathrm{~d}_{z}^{2}$ orbital was found to be further stabilised in $C_{3 v}$ symmetry; however, coordination of a neutral Lewis base $L$ to $\left[T h(C p)_{3}\right]$ on the $z$-axis would lead to destabilisation of the $6 d_{z}{ }^{2} a_{1}{ }^{\prime}$ orbital. Therefore the hypothetical complexes $\left[\mathrm{Th}(\mathrm{Cp})_{3}(\mathrm{~L})\right]$, in approximate $C_{3 v}$ symmetry, are predicted to exhibit $5 f^{1}$ valence configurations. ${ }^{14 a}$ Further calculations by Kaltsoyannis and Bursten on the $\mathrm{Ce}(\mathrm{III})$ homologue showed the importance of relativistic effects in $\left[\mathrm{Th}(\mathrm{Cp})_{3}\right]$ adopting the $6 \mathrm{~d}^{1}$ configuration. ${ }^{14 c, e} \mathrm{~A}$ qualitative agreement between calculated and experimental absorption spectra of $\left[\mathrm{Th}(\mathrm{Cp})_{3}\right]$ was achieved with these methods but several transitions could not be assigned. ${ }^{14 c, 15,29}$

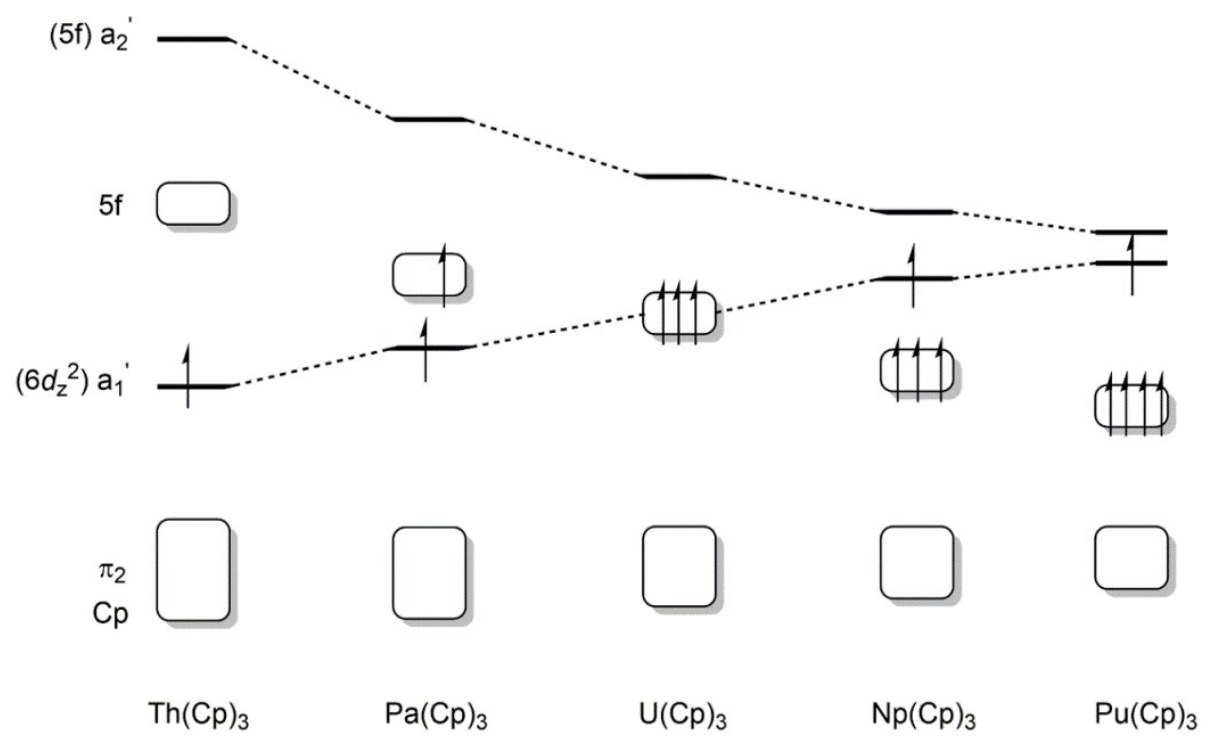

Figure 2. Qualitative $M O$ diagrams of $\left[\mathrm{An}(\mathrm{Cp})_{3}\right]$, extracted from Bursten and co-workers. ${ }^{14 a}$

The first heteroleptic $\mathrm{Th}(\mathrm{III})$ complex, $\left[\mathrm{Th}\left(\mathrm{Cp}^{*}\right)_{2}\left\{{ }^{i} \operatorname{PrNC}(\mathrm{Me}) \mathrm{N}^{i} \mathrm{Pr}\right\}\right]\left(6, \mathrm{Cp}^{*}=\mathrm{C}_{5} \mathrm{Me}_{5}\right)$, was prepared by the reduction of $\left[\mathrm{Th}\left(\mathrm{Cp}^{*}\right)_{2}\left\{{ }^{i} \mathrm{PrNC}(\mathrm{Me}) \mathrm{N}^{i} \mathrm{Pr}\right\}\right]\left[\mathrm{BMePh}_{3}\right]$ (formed in situ from the reaction of $\mathrm{BPh}_{3}$ with $\left.\left[\mathrm{Th}\left(\mathrm{Cp}^{*}\right)_{2}\left\{{ }^{i} \operatorname{PrNC}(\mathrm{Me}) \mathrm{N}^{\prime} \mathrm{Pr}\right\}(\mathrm{Me})\right]\right)$ with $\mathrm{KC}_{8}$ in diethyl ether (Scheme 6). ${ }^{30}$ The weakly coordinating anion $\left[\mathrm{BPh}_{3} \mathrm{Me}\right]^{-}$is a favourable leaving group compared to $\mathrm{Cl}^{-}$. Complex 6 was structurally authenticated and the characterisation data showed many similarities to those reported 
for 4-5. Complex 6 exhibited one resonance in the X-band EPR spectrum at room temperature $\left(g_{\text {iso }}\right.$ $=1.871)$, consistent with a $6 d^{1}$ valence configuration. Additionally, the electronic spectrum ${ }^{2}{ }^{2}{ }^{\top}{ }^{1111 j}$ shows strong absorptions at 575 and $725 \mathrm{~nm}$, which were ascribed to $6 \mathrm{~d}$ to $5 \mathrm{f}$ transitions and closely matched by those predicted with DFT calculations. Calculations verified a ground state doublet for 6 with one unpaired electron localised in a $d_{z}^{2}$ orbital and the $5 f^{1}$ level 0.91 eV higher in energy. Mulliken analysis showed that the d-orbital manifold had a spin density of 0.94 electrons. Extension of these calculations to homologous early An complexes showed that $\mathrm{Pa}$ (III) should exhibit a $5 f^{2}$ valence configuration, rather than $6 d^{1} 5 f^{1}$ or $6 d^{2}$. Significant orbital mixing was observed between the $5 f$ orbital of the An centre and the $\mathrm{Cp}$ ring and was shown to increase with Z. However, as previously discussed, this aspect does not necessarily involve an increase in the covalency of the bonding interactions. ${ }^{15}$
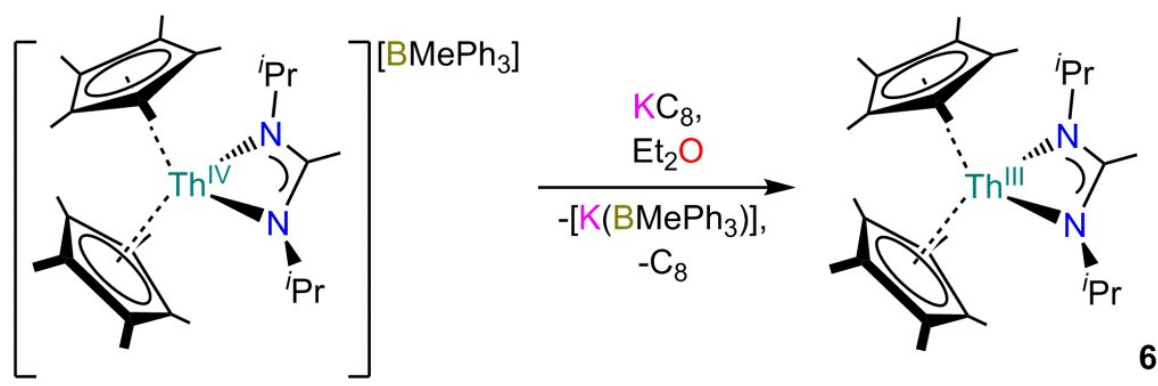

Scheme 6. Synthesis of $\left[\mathrm{Th}\left(\mathrm{Cp}^{*}\right)_{2}\left\{\operatorname{PrNC}(\mathrm{Me}) \mathrm{N}^{i} \mathrm{Pr}\right\}\right](6)$ via reduction of $\left[\mathrm{Th}\left(\mathrm{Cp}^{*}\right)_{2}\left\{{ }^{i} \mathrm{PrNC}(\mathrm{Me}) \mathrm{N}^{i} \mathrm{Pr}\right\}\right]\left[\mathrm{BMePh}_{3}\right]$ with $\mathrm{KC}_{8} \cdot{ }^{30}$

An additional homoleptic Th(III) Cp complex $\left[\mathrm{Th}\left(\mathrm{C}_{5} \mathrm{Me}_{4} \mathrm{H}\right)_{3}\right]$ (7) was synthesised by the reduction of "[Th( $\left.\left(\mathrm{C}_{5} \mathrm{Me}_{4} \mathrm{H}\right)_{3}\right]\left[\mathrm{BPh}_{4}\right]$ " (formed in situ from $\left[\mathrm{Th}\left(\mathrm{C}_{5} \mathrm{Me}_{4} \mathrm{H}\right)_{3}(\mathrm{Me})\right]$ and $\left[\mathrm{Et}_{3} \mathrm{NH}\right]\left[\mathrm{BPh}_{4}\right]$ ) or $\left[\mathrm{Th}\left(\mathrm{C}_{5} \mathrm{Me}_{4} \mathrm{H}\right)_{3}(\mathrm{Br})\right]$ with $\mathrm{KC}_{8}$, with the latter route giving the highest yield (58\%) (Scheme 7). ${ }^{31}$ Complex 7 was structurally authenticated and microanalysis results obtained were in good agreement with predicted values. In common with 4-6 one signal was observed in the X-band EPR spectrum of 7 in toluene at room temperature $\left(g_{\text {iso }}=1.92\right)$ and four broad intense absorptions were observed in the visible spectrum between $390-640 \mathrm{~nm} \cdot{ }^{31}$ The homoleptic compounds $4,{ }^{23} 5^{25}$ and $7^{30}$ exhibit pseudo- $\mathrm{D}_{3 \mathrm{~h}}$ trigonal planar symmetry in the solid state $\left[\Sigma_{\mathrm{Cp}-\mathrm{Th}-\mathrm{Cp}}: 4: 360.00(7)^{\circ} ; \mathbf{5}\right.$ : $357.0(2)^{\circ} ; 7: 359.97(7)^{\circ}$ ], with the metal centre located in the centre of an idealised equilateral 
triangle defined by the based on the centroids of the Cp rings (Figure 3). The Th $\cdots \mathrm{Cp}$ centroid

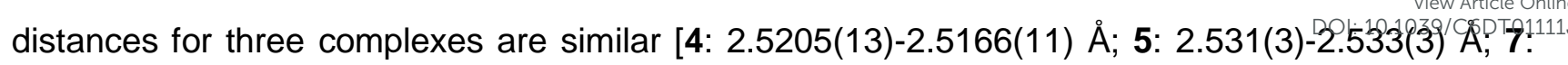
$2.5508(10) \AA]$; in all cases these are shorter than those in the respective Th(IV) precursors $\left[\mathrm{Th}\left(\mathrm{Cp}^{\prime \prime}\right)_{3}(\mathrm{Cl})\right][2.562(5)-2.568(5) \AA ̊],\left[\mathrm{Th}\left(\mathrm{Cp}^{\dagger \dagger}\right)_{3}(\mathrm{Cl})\right][2.578(4)-2.585(4) \AA]$ and $\left[\mathrm{Th}\left(\mathrm{C}_{5} \mathrm{Me}{ }_{4} \mathrm{H}\right)_{3}(\mathrm{Br})\right]$ [2.576 ̊ mean]. This can be attributed to the halides in the Th(IV) complexes reducing the net interaction of the $\mathrm{Cp}$ ligands with the metal centres and the relatively low repulsion of the $6 \mathrm{~d}_{z}^{2}$ electrons in 4, $\mathbf{5}$ and $\mathbf{7}$ as they do not point towards the Cp rings. Very recently, Evans and coworkers reported the synthesis of a mixed valent Th(III)/Th(IV) hydride from a Th(II) precursor, ${ }^{32}$ which will be covered in Section 5 .

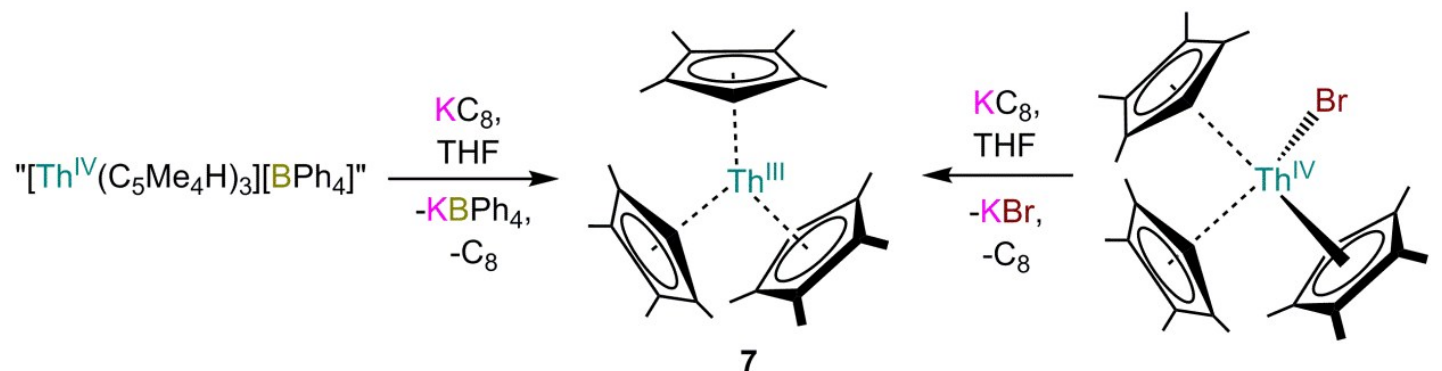

Scheme 7. Synthesis of $\left.\left[\mathrm{Th}\left(\mathrm{C}_{5} \mathrm{Me}_{4} \mathrm{H}\right)_{2}{ }^{i} \mathrm{PrNC}(\mathrm{Me}) \mathrm{N}^{\prime} \mathrm{Pr}\right\}\right](7)$ via reduction of "[Th( $\left.\left(\mathrm{C}_{5} \mathrm{Me}_{4} \mathrm{H}\right)_{3}\right]\left[\mathrm{BPh}_{4}\right]$ " or $\left[\mathrm{Th}\left(\mathrm{C}_{5} \mathrm{Me}_{4} \mathrm{H}\right)_{3}(\mathrm{Br})\right]$ with $\mathrm{KC}_{8} .{ }^{31}$ 

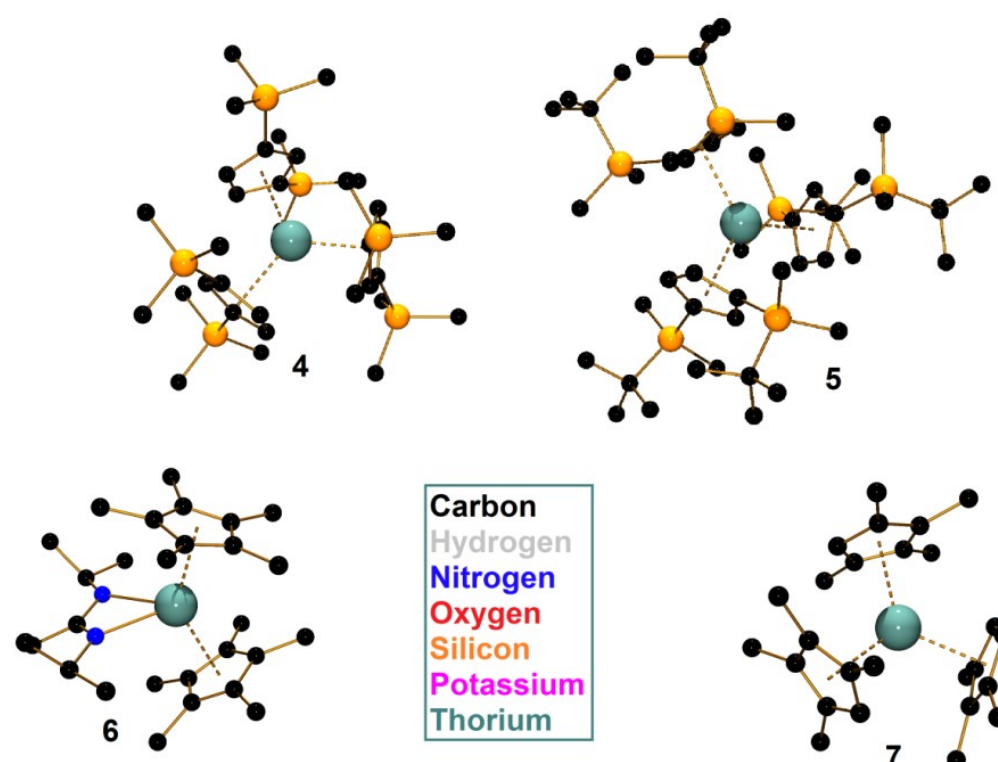

\begin{tabular}{|l|}
\hline Carbon \\
Hydrogen \\
Nitrogen \\
Oxygen \\
Silicon \\
Potassium \\
Thorium \\
\hline
\end{tabular}
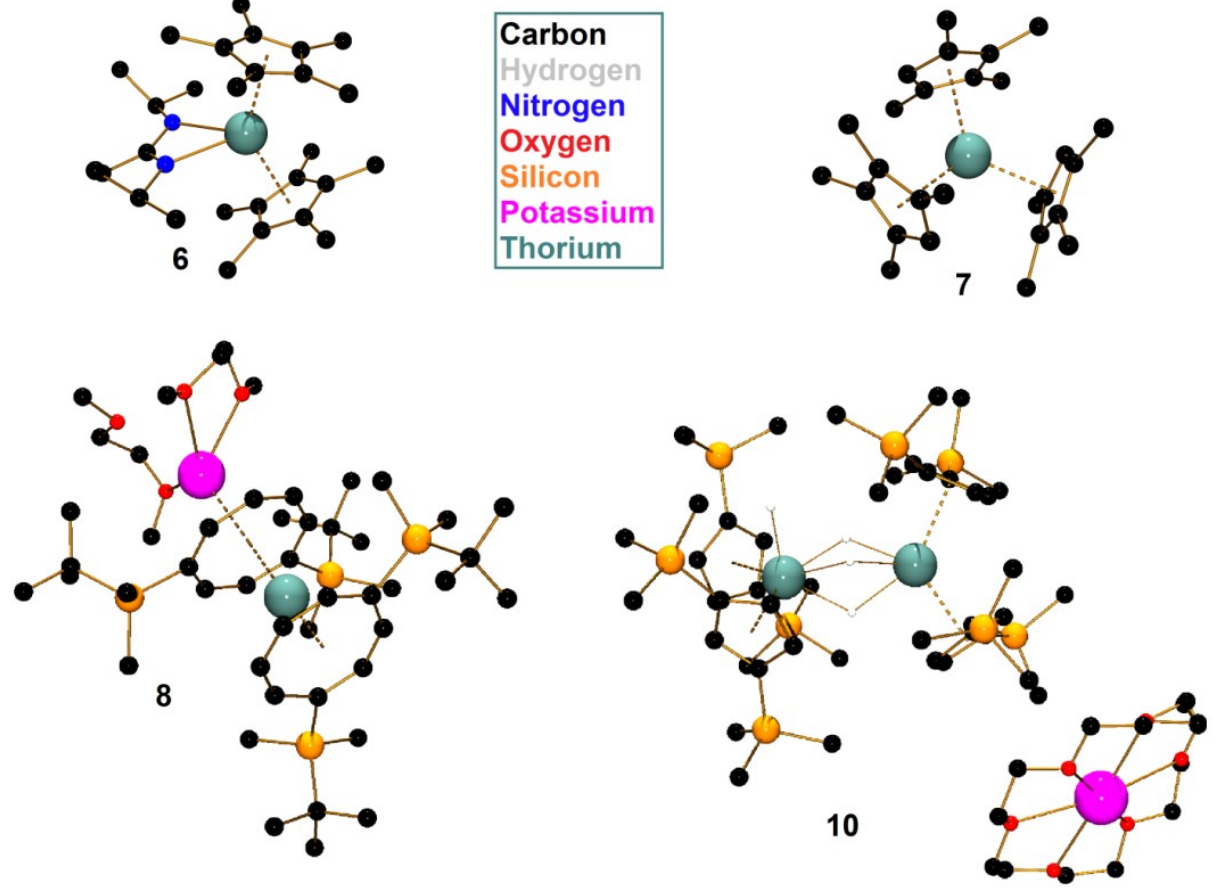

Figure 3. The structurally authenticated Th(III) complexes $4,{ }^{23} \mathbf{5},{ }^{25} \mathbf{6},{ }^{30} \mathbf{7},{ }^{31} \mathbf{8}^{33}$ and $\mathbf{1 0} .^{32}$ In $\mathbf{4 - 8}$ hydrogen atoms have been omitted for clarity. In 10 one $\mathrm{Et}_{2} \mathrm{O}$ molecule and all the hydrogen atoms have been omitted with the exception of bridging and terminal hydrides.

\subsection{Cyclooctatetraenyl complexes}

Over a decade after the structure of $\mathbf{4}$ was reported, Cloke and co-workers disclosed the synthesis of the $\mathrm{Th}(\mathrm{III})$ substituted cyclooctatetraenyl $(\mathrm{COT})$ complex $\left[\mathrm{K}(\mathrm{DME})_{2}\right]\left[\mathrm{Th}\left(\mathrm{COT}^{\mathrm{t \dagger}}\right)_{2}\right]\left(\mathbf{8},\left(\mathrm{COT}^{\mathrm{t \dagger}}=\right.\right.$

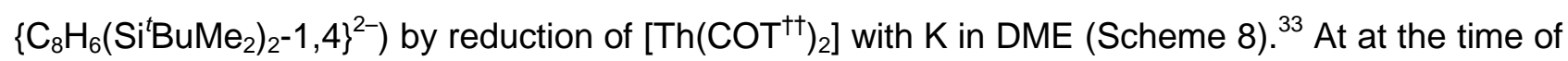
publication $\mathbf{8}$ was the second example of a structurally authenticated Th(III) complex and it remains a unique case in the literature as the only one that does not contain substituted $\mathrm{Cp}$ ligands (Figure 3). It is structurally analogous with the $\mathrm{U}(\mathrm{III})$ homologue $\left[\mathrm{K}(\mathrm{DME})_{2}\right]\left[\mathrm{U}\left(\mathrm{COT}^{\dagger \dagger}\right)_{2}\right]$, whilst it presents remarkable differences with the $\mathrm{Th}(\mathrm{IV})$ precursor $\left[\mathrm{Th}\left(\mathrm{COT}^{\mathrm{t \dagger}}\right)_{2}\right]$, due to the effects of the occluded 
alkali metal cation and the increased ionic radius of the Th(III) centre in $\mathbf{8}$. This is mirrored by the

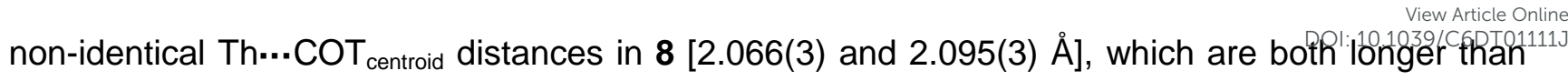
those seen in $\left[\mathrm{Th}\left(\mathrm{COT}^{\dagger \dagger}\right)_{2}\right][1.999(7) \AA]^{33}$ In common with 3-7, 8 displays an isotropic signal in the X-band EPR spectrum in solution at room temperature $(g=1.916)$ and a powdered sample gave a highly axial spectrum $\left(g_{\|}=1.981 ; g_{\perp}=1.887 ; g_{\mathrm{av}}=1.918\right)$. Cooling the powdered sample down to $110 \mathrm{~K}$ gave rise to the appearance of hyperfine interactions. The solution magnetic moment of 8 at room temperature in $d_{8}$-THF $\left(1.20 \mu_{\mathrm{B}}\right)$ was lower than would be expected for one unpaired electron $\left(1.73 \mu_{\mathrm{B}}\right)$, which the authors attributed to mixing of low-lying excited states with the ground-state magnetic component. The magnetic susceptibility was found to be higher at $199 \mathrm{~K}\left(1.41 \mu_{\mathrm{B}}\right)$, in agreement with this hypothesis. Finally, the UV-vis spectrum of dark green $\mathbf{8}$ exhibited a similar absorption profile to those shown by $4^{25}$ and $6{ }^{30}$ albeit shifted to the red, with two strong broad absorptions with maxima at 705 and $826 \mathrm{~nm}$ assigned as $6 \mathrm{~d}$ to $5 \mathrm{f}$ transitions. ${ }^{33}$

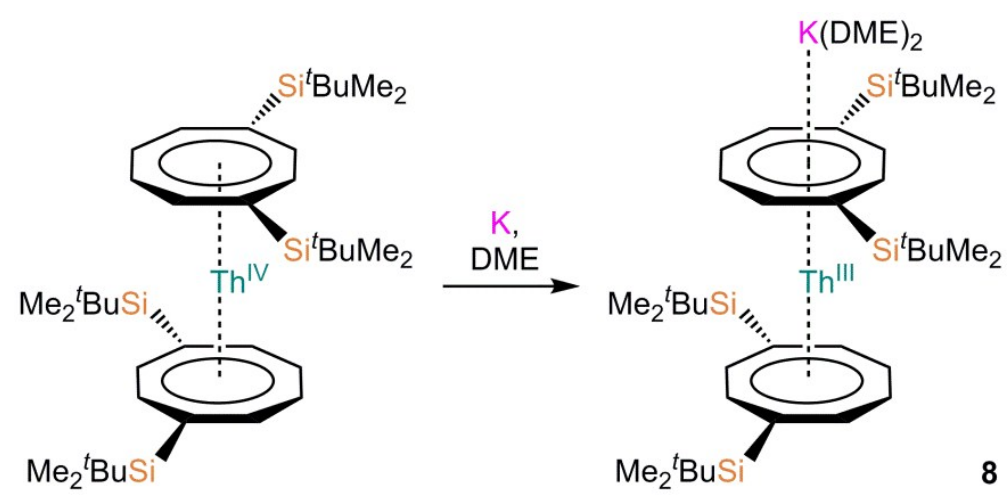

Scheme 8. Synthesis of $\left[\mathrm{K}(\mathrm{DME})_{2}\right]\left[\mathrm{Th}\left(\mathrm{COT}^{\dagger \dagger}\right)_{2}\right](8)$ via reduction of $\left[\mathrm{Th}\left(\mathrm{COT}^{+\dagger}\right)_{2}\right]$ with $\mathrm{K}^{33}$

The $\mathrm{AnL}_{2}{ }^{-}$coordination motif and symmetry of 8 contrasts with the $\mathrm{AnL}_{3}$ formulations of 1-7; as such the interactions of thorium $5 f$ and $6 \mathrm{~d}$ orbitals with the ligand group orbitals, and therefore the ordering of valence molecular orbitals, are expected to differ considerably. Before the disclosure of 8 and its uranium homologue complexes of the general formula $\left[\mathrm{An}^{\text {III }}(\mathrm{COT})_{2}\right]^{-}$were rare, in contrast with the large number of analogous $\left[\mathrm{Ln}^{\prime \prime \prime}(\mathrm{COT})_{2}\right]^{-} \mathrm{Ln}$ complexes. Of most relevance here, the isolation of $\left[\mathrm{Ce}(\mathrm{COT})_{2}\right]^{-}$was taken as strong evidence that $\left[\mathrm{Th}(\mathrm{COT})_{2}\right]^{-}$or a substituted analogue with increased kinetic stabilisation could be sensible synthetic targets. This hypothesis was further supported by the high symmetry of the bis-COT scaffold and consideration 
of the stabilisation of the $d_{z}^{2}$ orbital when relativistic effects are taken into account (Figure 4). ${ }^{33}$

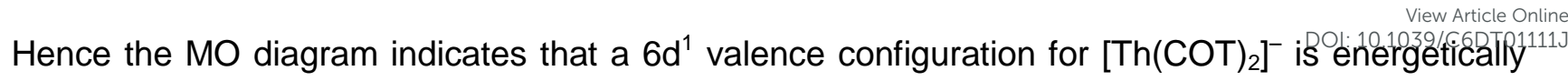
favoured over the $5 f^{1}$ alternative, concurring with previous investigations carried out by Bursten and Kaltsoyannis for $\left[\mathrm{Th}(\mathrm{Cp})_{3}\right]^{15,15}$

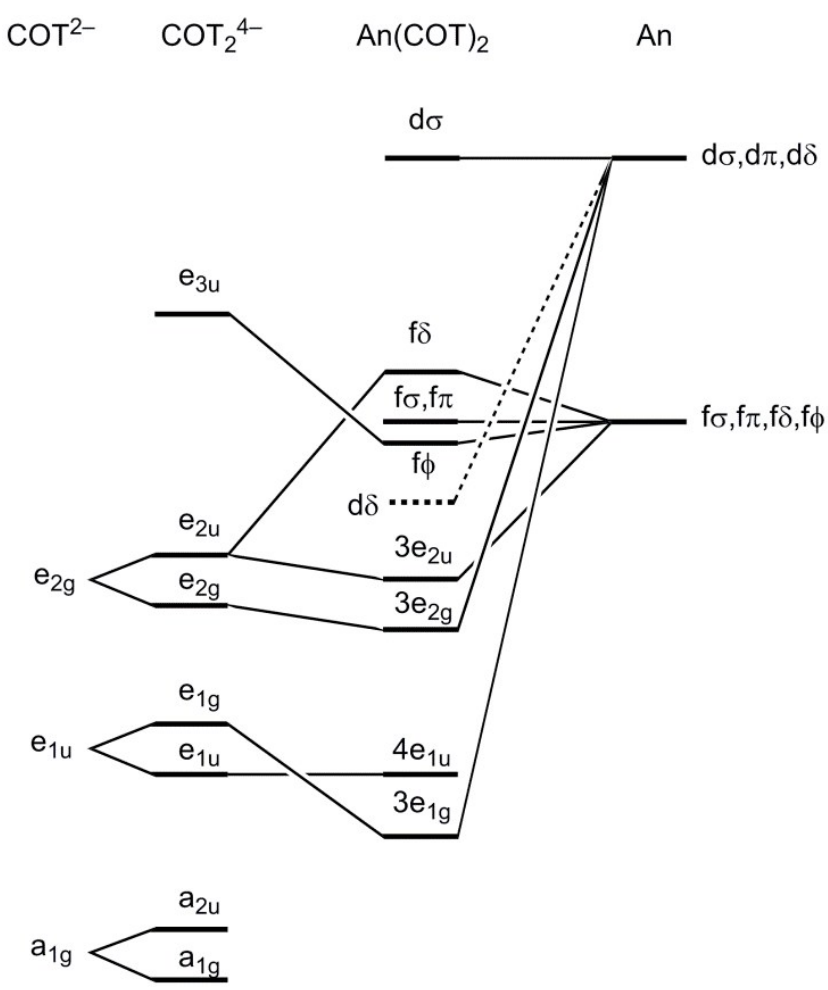

Figure 4. MO diagram for $\mathrm{An}(\mathrm{COT})_{2}$ complexes extracted from Cloke's study in $1999 .{ }^{33}$ The inclusion of relativistic effects is represented by the dashed line, leading to the stabilisation of the $6 d_{z}^{2}$-based orbital.

\section{Synthesis and properties of Th(II) complexes}

As $\operatorname{Th}(\mathrm{II})$ is predicted to be even harder to access than $\mathrm{Th}(\mathrm{III})$ based on standard reduction potential data $\left[\mathrm{E}^{\ominus} \mathrm{Th}(\mathrm{III}) \rightarrow \operatorname{Th}(\mathrm{II})-4.9 \mathrm{~V}\right.$, cf. $\left.\mathrm{Th}(\mathrm{IV}) \rightarrow \operatorname{Th}(\mathrm{III})-3.7 \mathrm{~V}\right],{ }^{12,26}$ the synthesis of $\operatorname{Th}(\mathrm{II})$ complexes is an exceptionally challenging task. Very recently, Evans and co-workers prepared the first structurally characterised $\mathrm{U}(\mathrm{II})^{34}$ and $\mathrm{Th}(\mathrm{II})^{26}$ complexes, thus extending the scope of lowvalent An chemistry by adding new accessible oxidation states. Following previous observations made by Lappert, the reduction of 4 with $\mathrm{KC}_{8}$ in THF in the presence of 18 -crown-6 or 2.2.2cryptand (Scheme 9) gave the Th(II) complexes $\left[\mathrm{Th}\left(\mathrm{Cp}{ }^{\prime \prime}\right)_{3}\right]\left[\mathrm{K}(18-c r o w n-6)(\mathrm{THF})_{2}\right](9 \mathrm{a})$ and 
$\left[\mathrm{Th}\left(\mathrm{Cp}^{\prime \prime}\right)_{3}\right]\left[\mathrm{K}(2.2 .2\right.$-cryptand) $)(9 \mathbf{b}$, Figure 5$) .{ }^{26}$ These compounds display metrical parameters

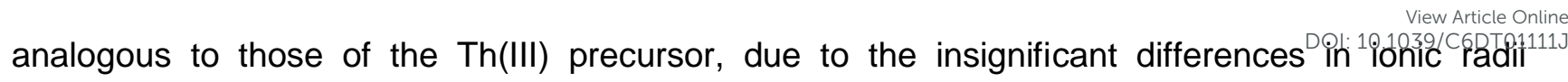
between the divalent and trivalent cations. The characterisation data of $\mathbf{9 a}$ and $\mathbf{9 b}$ and DFT calculations performed on full models were both consistent with a diamagnetic $6 d^{2}$ valence configuration, with both electrons occupying the $d_{z}^{2}$-like orbital. Interestingly, thorium is the first non-d-transition metal to display such a configuration. Solutions of $\mathbf{9 a}$ and $\mathbf{9 b}$ in THF have a deep green coloration and their UV-vis spectra showed very strong absorptions at $650 \mathrm{~nm}(\varepsilon=23,000$ $\mathrm{M}^{-1} \mathrm{~cm}^{-1}$ ) that were far more intense than any of those exhibited by $4 .{ }^{25}$ The electronic structures and An-ligand interactions for the $\mathrm{An}(\mathrm{II})$ complexes $\left[\mathrm{An}(\mathrm{Cp})_{3}\right]^{-}(\mathrm{An}=\mathrm{Th}-\mathrm{Am})$ in THF have recently been assessed by scalar DFT studies. ${ }^{35}$ This work verifies the experimentally observed $6 d^{2}$ valence configuration of $9 \mathrm{a}$, and shows that $\mathrm{Th}(\mathrm{II})$ is the most difficult $\left[\mathrm{An}(\mathrm{Cp})_{3}\right]^{-}$complex to access for the early Ans.
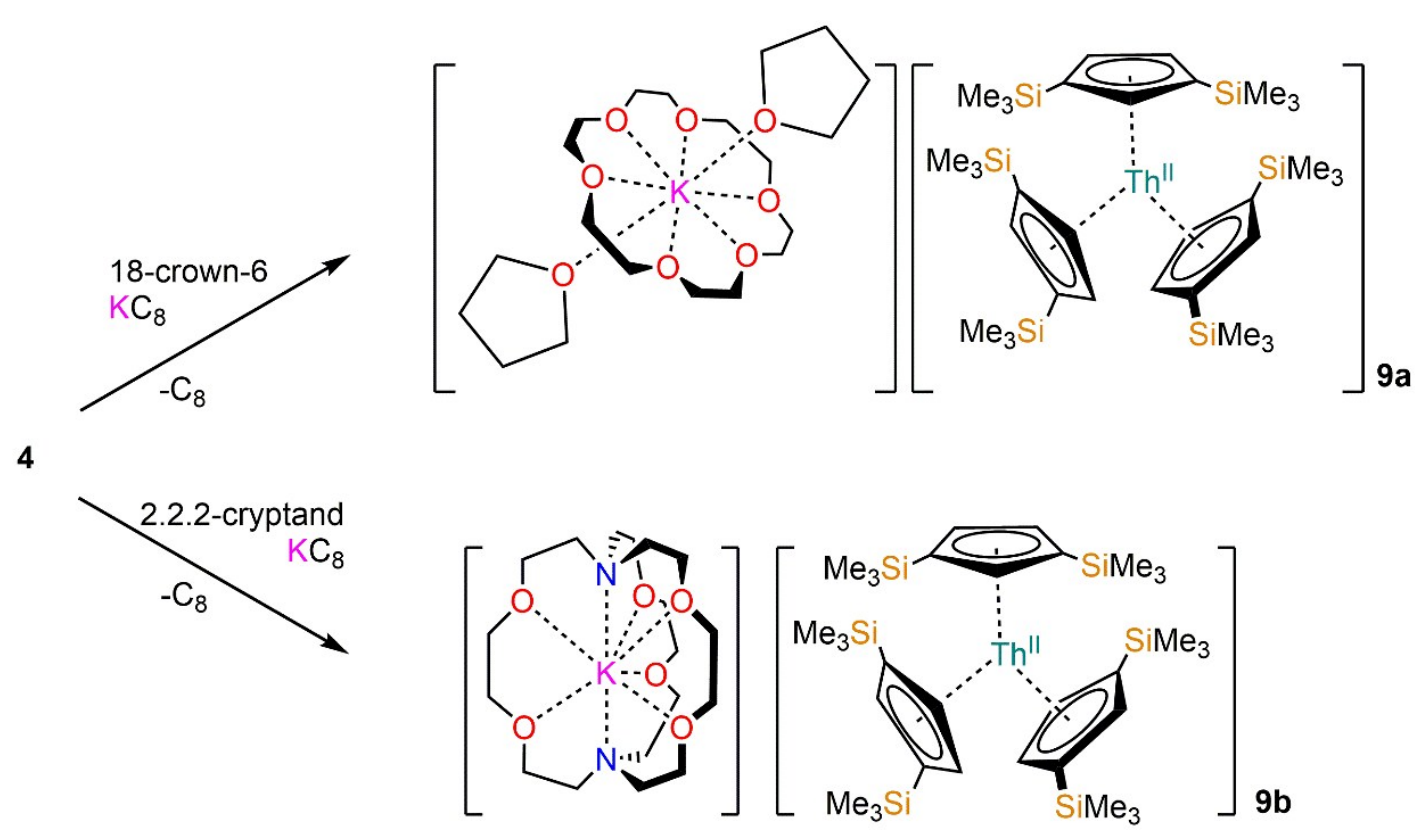

Scheme 9. Synthesis of $\left[\mathrm{Th}\left(\mathrm{Cp}^{\prime \prime}\right)_{3}\right]\left[\mathrm{K}(18-\mathrm{crown}-6)(\mathrm{THF})_{2}\right](9 \mathrm{a})$ and $\left[\mathrm{Th}\left(\mathrm{Cp} \mathrm{p}_{3}\right][\mathrm{K}(2.2 .2-\mathrm{cryptand})]\right.$ (9b) via reduction of $4 .{ }^{26}$ 

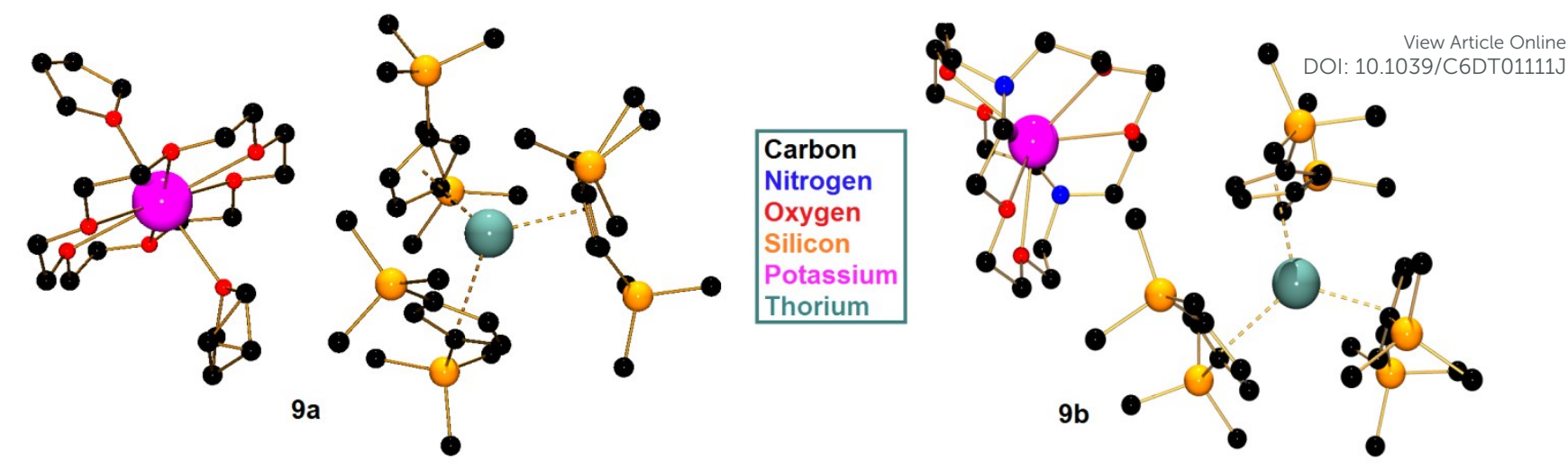

Figure 5. The structurally authenticated Th(II) complexes $9 a$ and $9 b .{ }^{26}$ Hydrogen atoms have been omitted for clarity.

\section{Reactivity of Th(III) complexes}

Herein, we divide reactivity studies of $\mathrm{Th}(\mathrm{III})$ complexes into two main classes: i) the reactivity of structurally authenticated examples; and, ii) the reactivity of Th(III) complexes that have not been characterised by single crystal X-ray diffraction. For the sake of brevity we will only cover the former classification in depth but it is noteworthy that Marks and co-workers reported reactivity studies of $\mathbf{1}$ and $\mathbf{3}$ with a range of substrates to give products that were not structurally characterised..$^{22}$ Complex 1 is oxidised by $I_{2}$ to give $\left[\mathrm{Th}(\mathrm{Cp})_{3}(\mathrm{I})\right]$ and $\mathrm{CDCl}_{3}$ to afford $\left[\mathrm{Th}(\mathrm{Cp})_{3}(\mathrm{Cl})\right]$. It reacts with a mixture of $\mathrm{NH}_{4} \mathrm{Cl}$ and THF to give the ring-opened product $\left[\mathrm{Th}(\mathrm{Cp})_{3}\left(\mathrm{OC}_{4} \mathrm{H}_{9}\right)\right]$. Methanolysis of $\mathbf{1}$ yielded [ $\left.\mathrm{Th}(\mathrm{OMe})_{4}\right]$, and the product from the reaction of $\mathbf{1}$ with $\mathrm{H}_{2}$ could not be identified. Complex 3 showed analogous reactivity with $\mathrm{I}_{2}, \mathrm{CHCl}_{3}$ and methanol, but in contrast no reaction was observed with $\mathrm{H}_{2}$ under the conditions employed. Reactivity studies of structurally authenticated Th(III) complexes are currently limited to a handful of examples, which is in stark contrast to $\mathrm{U}(\mathrm{III})$ chemistry where reactivity studies are legion. ${ }^{5}$ This paucity can be attributed to both the comparative dearth of $\mathrm{Th}(\mathrm{III})$ complexes to employ as starting materials and to difficulties encountered in manipulations of these highly oxophilic materials.

It is germane to note that reactivity studies of synthetic equivalents (or 'synthons') of low oxidation state thorium complexes have thrived in comparison, but an in-depth discussion is beyond the scope of this review. In these complexes, redox non-innocent ligands are utilised to store electrons following reduction of Th(IV) precursors, giving reactive Th(IV) complexes that can 
mimic the behaviour of low oxidation state analogues. These synthons are typically more stable

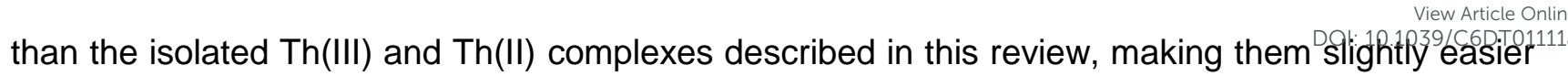
to handle (though these are still highly air- and moisture-sensitive). Th(II) synthons in particular have been investigated extensively, with the first examples reported by Erker, ${ }^{36}$ Marks $^{37}$ and Scherer. ${ }^{38}$ More recently Gambarotta ${ }^{39}$ and Zi and Walter ${ }^{40}$ have carried out pioneering reactivity studies on such complexes.

Lappert reported that the reaction of $\mathbf{4}$ with "wet" toluene (containing trace amounts of water) gave the dimeric Th(IV) complex $\left[\left\{\mathrm{Th}\left(\mathrm{Cp}^{\prime \prime}\right)_{3}\right\}_{2}(\mu-\mathrm{O})\right]$ almost exclusively (Scheme 10). ${ }^{25,25}$ No solid state structure of $\left[\left\{\mathrm{Th}\left(\mathrm{Cp}^{\prime \prime}\right)_{3}\right\}_{2}(\mu-\mathrm{O})\right]$ was obtained in these studies, with identification of the product based upon ${ }^{1} \mathrm{H}$ NMR spectroscopy and elemental analysis. Lappert also reported the purposeful oxidation of 4 with ${ }^{t} \mathrm{BuCl}$ to afford the expected $\mathrm{Th}(\mathrm{IV})$ complex $\left[\left\{\mathrm{Th}(\mathrm{Cp})_{3}(\mathrm{Cl})\right]\right.$ in excellent yield (Scheme 10). ${ }^{25}$ This transformation illustrates the tendency for Th(III) complexes to perform a single electron transfer with reagents to give Th(IV) products. However, complex 4 was reported to not react with THF, DME, $\mathrm{CO}$ and $\mathrm{H}_{2}$ in the same study.

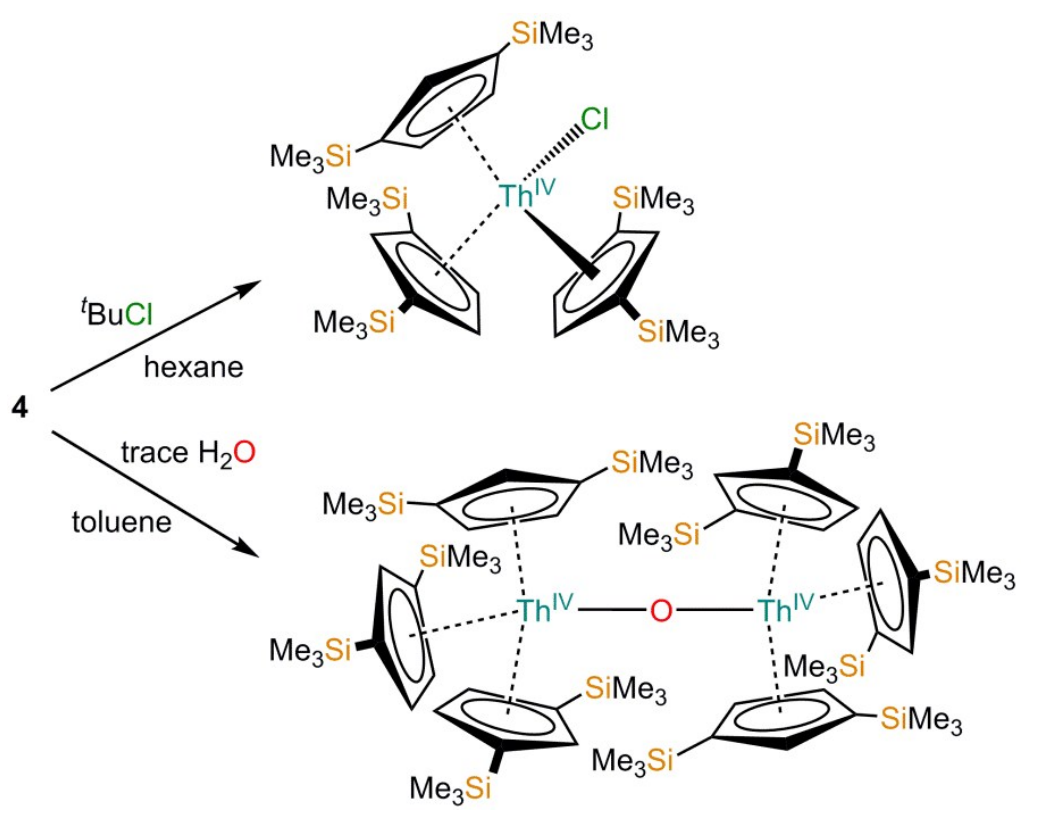

Scheme 10. Reaction of 4 with ${ }^{t} \mathrm{BuCl}$ and trace $\mathrm{H}_{2} \mathrm{O}$ to give $\left[\left\{\operatorname{Th}(\mathrm{Cp})_{3}(\mathrm{Cl})\right]\right.$ and $\left[\left\{\operatorname{Th}(\mathrm{Cp} ")_{3}\right\}_{2}(\mu-\mathrm{O})\right]$, respectively. ${ }^{25,25}$

Evans and co-workers investigated the reactivity of the Th(III) complex 7 with TEMPO (TEMPO = 2,2,6,6-tetramethyl-piperidin-1-oxyl radical), yielding the Th(IV) complex 
$\left[\mathrm{Th}\left(\mathrm{C}_{5} \mathrm{Me}_{4} \mathrm{H}\right)_{3}(\mathrm{TEMPO})\right]$ (Scheme 11). ${ }^{41}$ The TEMPO radical oxidises 7 , with incorporation of a

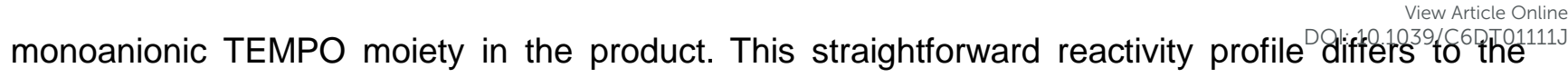
corresponding $\mathrm{U}(\mathrm{III})$ chemistry, where reactions with TEMPO can potentially generate a variety of products dependent on the ancillary ligands due to uranium having a wider range of accessible oxidation states. ${ }^{5 b}$ For example, complexes have been isolated that contain terminal unsupported $\mathrm{U}(\mathrm{V})=\mathrm{O}$ multiple bonds, with the reactions presumably proceeding by a $\mathrm{U}(\mathrm{IV})$ intermediate and cleavage of the $\mathrm{N}-\mathrm{O}$ bond to eliminate tetramethylpiperidine. ${ }^{42}$ As TEMPO is a relatively strong oxidant the reductive capability of Th(III) complexes had not yet been exploited.

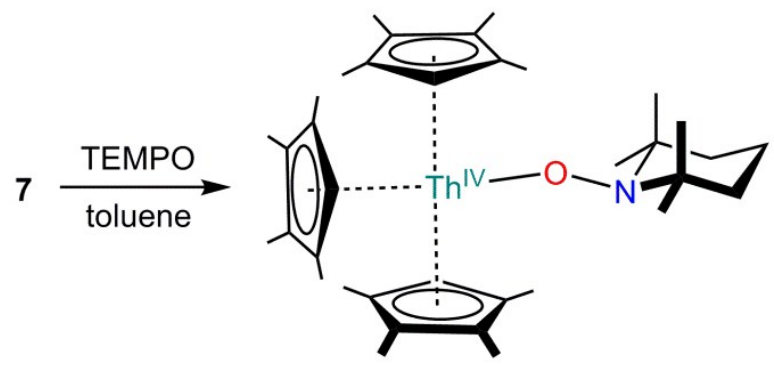

Scheme 11. Reaction of 7 with TEMPO to give $\left[\mathrm{Th}\left(\mathrm{C}_{5} \mathrm{Me}_{4} \mathrm{H}\right)\left(\right.\right.$ TEMPO) ${ }^{41}$

Cloke and co-workers have previously shown that a family of mixed sandwich $\mathrm{U}(\mathrm{III})$ complexes can activate small molecules such as $\mathrm{CO}$ and $\mathrm{CO}_{2}$ to give diverse and interesting outcomes. ${ }^{43}$ Attempts to translate this chemistry to thorium were attempted, however during the attempted synthesis of analogous mixed sandwich Th(III) complexes disproportionation to a Th(IV) complex and thorium metal was observed. ${ }^{44}$ As a result, the in situ reactivity of the Th(IV) complex $\left[\mathrm{Th}\left(\mathrm{COT}^{\ddagger \ddagger}\right)\left(\mathrm{Cp}^{\star}\right)(\mathrm{I})\right]\left(\mathrm{COT}^{\ddagger \ddagger}=\left\{\mathrm{C}_{8} \mathrm{H}_{6}\left(\mathrm{Si}^{i} \mathrm{Pr}_{3}\right)_{2}-1,4\right\}^{2-}\right)$ with excess $\mathrm{CO}_{2}$ in the presence of $\mathrm{Na} / \mathrm{K}$ alloy was investigated. This reaction gave a mixture of products, with $\left[\left\{\mathrm{Th}\left(\mathrm{COT}^{\ddagger \ddagger}\right)\left(\mathrm{Cp}^{\star}\right)\right\}_{2}\left(\mu-\mathrm{K}^{1}: \mathrm{K}^{2}-\mathrm{CO}_{3}\right)\right]$ and $\left[\left\{\mathrm{Th}\left(\mathrm{COT}^{\ddagger \ddagger}\right)\left(\mathrm{Cp}^{*}\right)\right\}_{2}\left(\mu-\mathrm{K}^{2}: \mathrm{K}^{2}-\mathrm{C}_{2} \mathrm{O}_{4}\right)\right]$ isolated in poor yields and identified by single crystal $\mathrm{X}$-ray diffraction (Scheme 12). ${ }^{44}$ The formation of these carbonate and oxalate products can be ascribed to a transient $\mathrm{Th}(\mathrm{III})$ complex generated by the reduction of $\left[\mathrm{Th}\left(\mathrm{COT}^{\ddagger \ddagger}\right)\left(\mathrm{Cp}^{\star}\right)(\mathrm{I})\right]$ with $\mathrm{Na} / \mathrm{K}$ alloy. It is also possible that a transmetallation reaction occurs between $\left[\operatorname{Th}\left(\mathrm{COT}^{\ddagger \ddagger}\right)\left(\mathrm{Cp}^{\star}\right)(\mathrm{I})\right]$ and sodium or potassium carbonate, however this pathway was shown to be unlikely. Whilst the carbonate bonding motif observed in $\left[\left\{\mathrm{Th}\left(\mathrm{COT}^{\ddagger \ddagger}\right)\left(\mathrm{Cp}^{*}\right)\right\}_{2}\left(\mu-\mathrm{K}^{1}: \mathrm{K}^{2}-\mathrm{CO}_{3}\right)\right]$ has considerable precedence in 
analogous $\mathrm{U}(\mathrm{III})$ chemistry, ${ }^{39 c, 45}$ the oxalate motif observed in $\left[\left\{\mathrm{Th}\left(\mathrm{COT}^{\ddagger \ddagger}\right)\left(\mathrm{Cp}^{\star}\right)\right\}_{2}\left(\mu-\mathrm{K}^{2}: \mathrm{K}^{2}-\mathrm{C}_{2} \mathrm{O}_{4}\right)\right]$

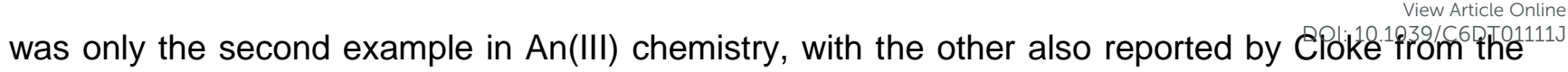
reaction of $\mathrm{CO}_{2}$ with $\left[\mathrm{U}\left(\mathrm{COT}^{\ddagger \ddagger}\right)\left(\mathrm{C}_{5} \mathrm{Me}_{4} \mathrm{R}\right)\right]\left(\mathrm{R}=\mathrm{Me}\right.$, Et, $\left.{ }^{\mathrm{P} r} \mathrm{,}{ }^{\mathrm{t}} \mathrm{Bu}\right) .{ }^{46}$
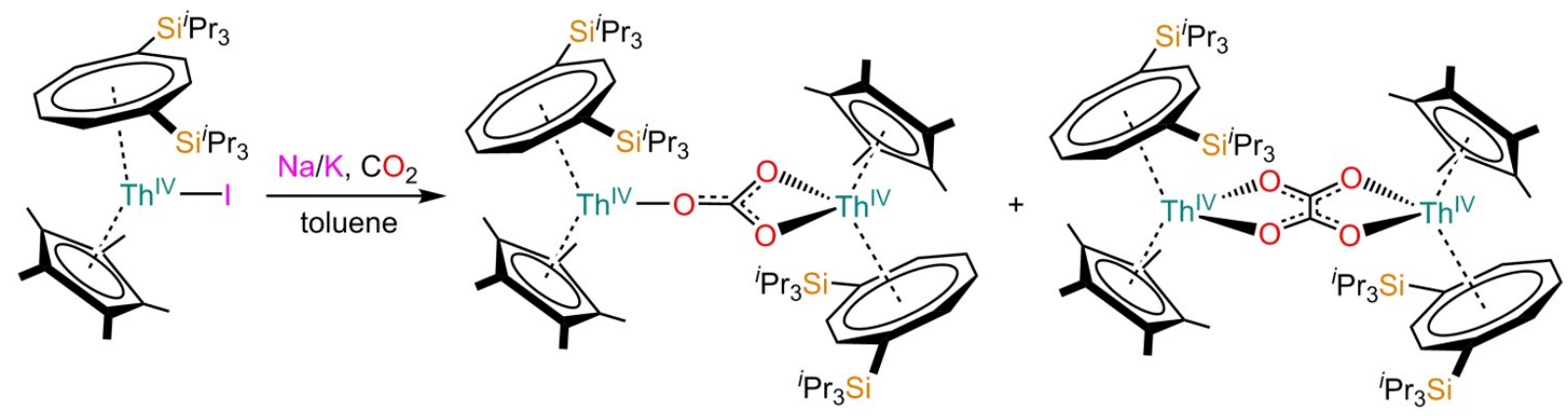

Scheme 12. Reaction of $\left[\mathrm{Th}\left(\mathrm{COT}^{\ddagger \ddagger}\right)\left(\mathrm{Cp}^{\star}\right)(\mathrm{I})\right]$ with $\mathrm{Na} / \mathrm{K}$ and $\mathrm{CO}_{2}$ to give $\left[\left\{\mathrm{Th}\left(\mathrm{COT}^{\ddagger \ddagger}\right)\left(\mathrm{Cp}^{\star}\right)\right\}_{2}\left(\mu-\mathrm{K}^{1}: \mathrm{K}^{2}-\right.\right.$ $\left.\left.\mathrm{CO}_{3}\right)\right]$ and $\left[\left\{\operatorname{Th}\left(\mathrm{COT}^{\ddagger \ddagger}\right)\left(\mathrm{Cp}^{*}\right)\right\}_{2}\left(\mu-\mathrm{K}^{2}: \mathrm{K}^{2}-\mathrm{C}_{2} \mathrm{O}_{4}\right)\right]^{44}$

Recently, we reported the reaction of 4 with $P_{4}$ to yield $\left[\left\{T h\left(C p^{\prime \prime}\right)_{3}\right\}_{2}\left(\mu-\eta^{1}: \eta^{1}-P_{4}\right)\right]$, with the dimeric structure possessing two Th(IV) centres bridged by a di-reduced cyclo- $\mathrm{P}_{4}$ fragment in a hitherto unknown $\eta^{1}: \eta^{1}$ binding mode for a $P_{4}$ unit (Scheme 13). ${ }^{47}$ Interestingly, the analogous U(III) complex, $\left[\mathrm{U}(\mathrm{Cp})_{3}\right]$, does not react with $\mathrm{P}_{4}$ under the same conditions and even at elevated temperatures. This observation, coupled with the fact that there have been several reports of U(III) complexes activating $\mathrm{P}_{4}{ }^{43,48}$ implies that in the tris-Cp" ligand environment Th(III) displays an elevated reduction potential over $\mathrm{U}(\mathrm{III})$. The standard reduction potential of $\mathrm{P}_{4}$ has been reported to be between -1.53 and $-1.98 \mathrm{~V},{ }^{49}$ therefore this report has experimentally confirmed for the first time the long-predicted reductive capability of Th(III) complexes.

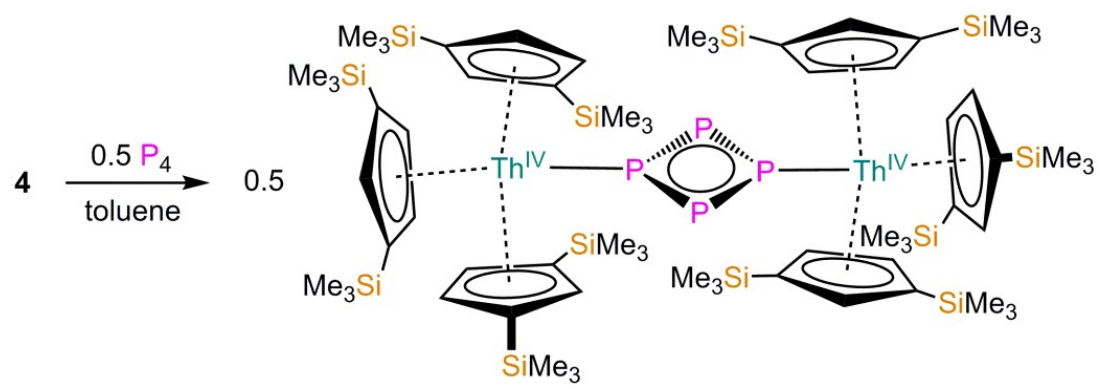

Scheme 13. Reaction of 4 with $P_{4}$ to give $\left[\left\{T h\left(C p^{\prime \prime}\right)_{3}\right\}_{2}\left(\mu-\eta^{1}: \eta^{1}-P_{4}\right)\right]^{47}$ 


\section{Reactivity of Th(II) complexes}

Initial reactivity studies of the $\mathrm{Th}(\mathrm{II})$ complexes $\mathbf{9 a}$ and $\mathbf{9 b}$ have already provided exciting sylintheetic avenues that are unique to this oxidation state. In the initial report by Evans and co-workers, 9a reacted as a $2 \mathrm{e}^{-}$reducing agent with 1,3,5,7-cyclooctatetraene, yielding the heteroleptic Th(IV) complex $\left[\mathrm{Th}(\mathrm{Cp} ")_{2}\left(\mathrm{C}_{8} \mathrm{H}_{8}\right)\right]$ and $[\mathrm{K}(18-\mathrm{crown}-6)]\left[\mathrm{Cp}^{\prime \prime}\right]$ (Scheme 14). ${ }^{26}$ More recently, 9a was shown to react with $\left[\mathrm{Et}_{3} \mathrm{NH}\right]\left[\mathrm{KBPh}_{4}\right]$ to afford the Th(IV) hydride complex $\left[\mathrm{Th}(\mathrm{Cp})_{3}(\mathrm{H})\right]$ and 4, which were identified by single crystal XRD and ${ }^{1} \mathrm{H}$ NMR spectroscopy (Scheme 15). ${ }^{32}$ The formation of $\left[\operatorname{Th}\left(\mathrm{Cp}^{\prime \prime}\right)_{3}(\mathrm{H})\right]$ implies that a $2 \mathrm{e}^{-}$process has occurred but the concomitant formation of 4 is likely due to a $1 \mathrm{e}^{-}$process; as such the overall mechanism of this reaction is unclear. In the same report, Evans and co-workers showed that $9 \mathrm{a}$ is capable of activating dihydrogen, leading to the formation of the first mixed-valent Th(III)/Th(IV) hydride complex, $\left[\left\{\mathrm{Th}\left(\mathrm{Cp}^{\prime \prime}\right)_{2}\right\}\left\{\mathrm{Th}(\mathrm{Cp})_{2}(\mathrm{H})\right\}(\mu-\mathrm{H})_{3}\right][\mathrm{K}(18$-crown6) $\left.\left(\mathrm{Et}_{2} \mathrm{O}\right)\right]\left(\mathbf{1 0}\right.$, Scheme 15). ${ }^{32}$ This result is particularly remarkable as the $\mathrm{Th}(\mathrm{III})$ analogue 4 does not react with dihydrogen under these conditions.

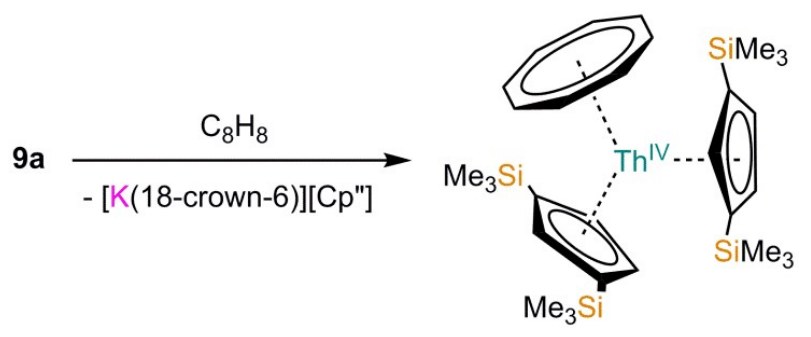

Scheme 14. Two electron reduction of $\mathrm{C}_{8} \mathrm{H}_{8}$ by $9 \mathrm{a}$ to give $\left[\mathrm{Th}(\mathrm{Cp} ")_{2}\left(\mathrm{C}_{8} \mathrm{H}_{8}\right)\right]^{26}$ 

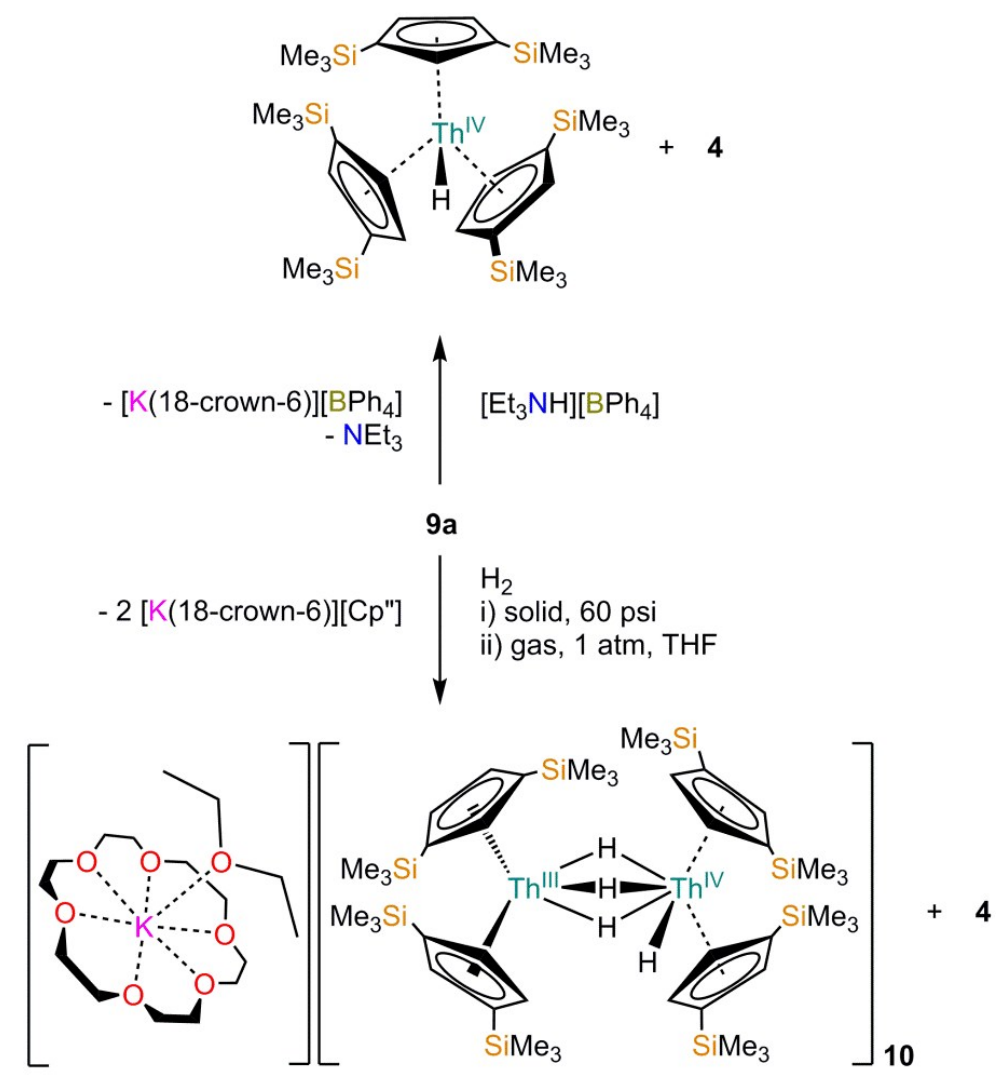

Scheme 15. Reactivity of $9 a$ with $\left[\mathrm{Et}_{3} \mathrm{NH}\right]\left[\mathrm{BPh}_{4}\right]$ and $\mathrm{H}_{2}$ : formation of the mixed valent $\mathrm{Th}(\mathrm{III}) / \mathrm{Th}(\mathrm{IV})$ hydride $\left[\left\{\operatorname{Th}\left(\mathrm{Cp}^{\prime \prime}\right)_{2}\right\}\left\{\operatorname{Th}\left(\mathrm{Cp}^{\prime \prime}\right)_{2}(\mathrm{H})\right\}(\mu-\mathrm{H})_{3}\right]\left[\mathrm{K}(18-\mathrm{crown} 6)\left(\mathrm{Et}_{2} \mathrm{O}\right)\right](\mathbf{1 0}) .{ }^{32}$

In the solid state structure of $\mathbf{1 0}$ the $\mathrm{Th}(\mathrm{IV})$ and $\mathrm{Th}(\mathrm{III})$ centres display similar metrical parameters, in common with other Th(III) and Th(IV) Cp complexes. IR and ${ }^{1} \mathrm{H}$ NMR spectroscopy could not provide conclusive information regarding the presence of hydrides in 10, which are necessary for the overall charge balance and mixed-valent formulation. However, the $6 d^{1}$ electronic configuration of one of the thorium centres was confirmed via EPR and optical spectroscopy. In common with 4-8 an isotropic signal was observed in the solution X-band EPR spectrum of 10 at room temperature $(g=1.88)$ but in contrast at $77 \mathrm{~K}$ a rhombic signal was observed $(g=1.98,1.94,1.76)$, unlike the axial and pseudo-axial spectra obtained for 4-8.The UVvis spectrum of $\mathbf{1 0}$ is analogous to that of $\mathbf{4}$, although the absorption band is broader (range 500 $650 \mathrm{~nm}$ ) and less intense. DFT calculations were in good agreement with the crystallographic information obtained for $\mathbf{1 0}$ and are consistent with the presence of distinct Th(III) and Th(IV) centres with localised oxidation states. It is noteworthy that in the same report the analogous compound $\left[\left\{\mathrm{Th}\left(\mathrm{Cp}^{*}\right)_{2}\right\}\left\{\mathrm{Th}\left(\mathrm{Cp}^{*}\right)_{2}(\mathrm{H})\right\}(\mu-\mathrm{H})_{3}\right][\mathrm{K}(18$-crown-6)(THF)] was obtained via reduction of 
$\left[\mathrm{Th}\left(\mathrm{Cp}^{*}\right)_{2}(\mathrm{H})(\mu-\mathrm{H})\right]_{2}$. Although this complex could not be structurally authenticated the

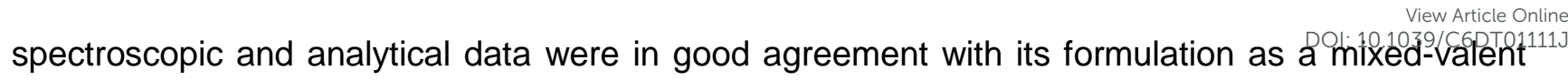
$\mathrm{Th}(\mathrm{III}) / \mathrm{Th}(\mathrm{IV})$ complex. Finally, in the same report Evans and co-workers showed that Th(IV) hydride species could be obtained from in situ formation of a Th(II) species in the presence of dihydrogen. Reduction of 7 with $\mathrm{KC}_{8}$ in the presence of dihydrogen gave the tuck-in $\mathrm{Th}(\mathrm{IV})$ hydride $\left[\mathrm{Th}\left(\mathrm{C}_{5} \mathrm{Me}_{4} \mathrm{H}\right)_{2}\left\{\eta^{1}: \eta^{5}-\mathrm{C}_{5} \mathrm{Me}_{3} \mathrm{H}\left(\mathrm{CH}_{2}\right)\right\}(\mathrm{H})\right][\mathrm{K}(2.2$.2-cryptand $)]$ together with the $\mathrm{Th}(\mathrm{IV})$ hydride $\left[\mathrm{Th}\left(\mathrm{C}_{5} \mathrm{Me}_{4} \mathrm{H}\right)_{3}(\mathrm{H})\right]\left(\right.$ Scheme 16). ${ }^{32}$

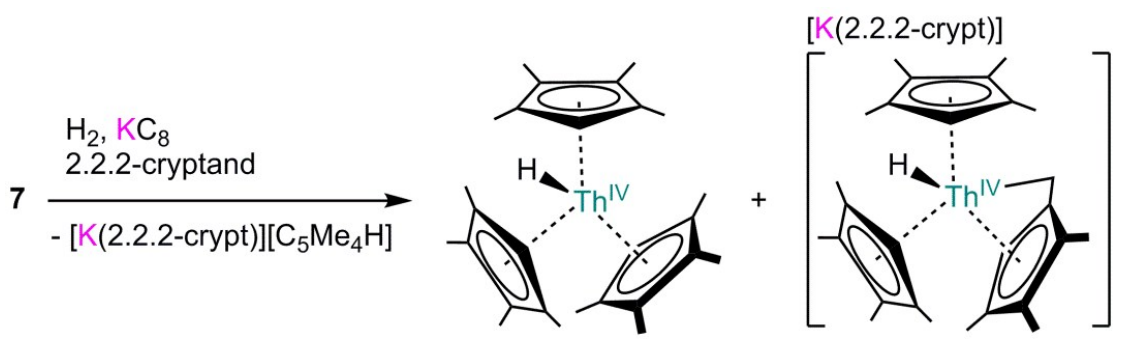

Scheme 16. Synthesis of Th(IV) hydrides from in situ formation of $\mathrm{Th}(\mathrm{II})$ in the presence of $\mathrm{H}_{2}{ }^{32}$

\section{Conclusions}

Although Th(III) complexes have been known for over forty years, and the first structurally authenticated example was reported thirty years ago, the field of low oxidation state thorium chemistry has yet to blossom. Th(III) complexes are not yet as diverse as those in U(III) chemistry due to the absence of $\operatorname{Th}(\mathrm{III})$ starting materials and synthetic routes are not as developed. However, the recent isolation and reactivity studies of the first Th(II) complexes implies that we are on the cusp of a renaissance in this field. Although these investigations are in their infancy, $\operatorname{Th}(\mathrm{III})$ reactivity studies have already provided a hitherto unknown structural motif of cyclo- $\mathrm{P}_{4}$, and pioneering work on $\mathrm{Th}(\mathrm{II})$ has now opened up $2 \mathrm{e}^{-}$processes at thorium centres for the first time. The extensive and ground-breaking small molecule activation chemistry exhibited by U(III) complexes in the last fifteen years, together with the considerable reduction potentials of low oxidation states of thorium, both strongly imply that the small molecule activation chemistry of low oxidation state thorium complexes could provide remarkable examples. Further to this, the physical properties of $\mathrm{Th}(\mathrm{III})$ and $\mathrm{Th}(\mathrm{II})$ complexes have already proved fascinating and there is much left to uncover and rationalise. Future investigations into low oxidation state thorium chemistry will 
provide results that deepen our understanding of actinide electronic structures and bonding regimes at a strategic juncture as thorium nuclear fuel cycles are now being actively pursuied.

\section{References}

1. D. Heuer, E. Merle-Lucotte, M. Allibert, M. Brovchenko, V. Ghetta and P. Rubiolo, Ann. Nucl. Energy, 2014, 64, 421.

2. P. Bagla, Science, $2015,350,726$.

3. CRC Handbook of Chemistry and Physics, $96^{\text {th }}$ edn., ed. W. M. Haynes, CRC Press, Boca Raton, 2015.

4. J. Arnold, T. L. Gianetti and Y. Kashtan, Nature Chem., 2014, 6, 554.

5. (a) S. T. Liddle, Angew. Chem. Int. Ed., 2015, 54, 8604; (b) L. R. Morss, N. M. Edelstein, J. Fuger and J. J. Katz, The Chemistry of the Actinide and Transactinide Elements, $3^{\text {rd }}$ ed., Springer, Dordrecht, 2006.

6. M. L. Neidig, D. L. Clark and R. L. Martin, Coord. Chem. Rev., 2013, 257, 394.

7. B. E. Bursten and R. J. Strittmatter, Angew. Chem. Int. Ed., 1991, 30, 321.

8. R. J. Baker, Coord. Chem. Rev., 2012, 256, 2843.

9. (a) S. T. Liddle and J. van Slageren, Actinide Single Molecule Magnets, in Lanthanides and Actinides in Molecular Magnetism, ed. R. A. Layfield and M. Murugesu, Wiley, Weinheim, 2015; (b) S. T. Liddle and J. van Slageren, Chem. Soc. Rev., 2015, 44, 6655; (c) F. Moro, D. P. Mills, S. T. Liddle and J. van Slageren, Angew. Chem. Int. Ed., 2013, 52, 3430.

10. (a) H. S. La Pierre and K. Meyer, Prog. Inorg. Chem., 2014, 58, 303; (b) B. M. Gardner and S. T. Liddle, Eur. J. Inorg. Chem., 2013, 3753; (c) O. P. Lam and K. Meyer, Polyhedron, 2012, 32, 1; (d) P. L. Arnold, Chem. Commun., 2011, 47, 9005; (e) O. T. Summerscales and F. G. N. Cloke, Struct. Bond., 2008, 127, 87; (f) I. Castro-Rodríguez and K. Meyer, Chem. Commun., 2006, 1353;

(g) W. J. Evans and S. A. Kozimor, Coord. Chem. Rev., 2006, 250, 911; (h) M. Ephritikhine, Dalton Trans., 2006, 2501; (i) I. Korobkov and S. Gambarotta, Prog. Inorg. Chem., 2005, 54, 321.

11. (a) A. R. Fox, S. C. Bart, K. Meyer and C. C. Cummins, Nature, 2008, 455, 341; (b) E. Lu and S. T. Liddle, Dalton Trans., 2015, 44, 12924. 
12. L. J. Nugent, R. D. Baybarz, J. L. Burnett and J. L. Ryan, J. Phys. Chem., 1973, 77, 1528w Article Online 13. (a) E. Hayek, T. Rehner and A. Frank, Monatsh. Chem., 1951, 82, 575; (b) G. W. Watt, D. M. Sowards and S. C. Malhotra, J. Am. Chem. Soc., 1957, 79, 4908; (c) R. J. Clark and J. D. Corbett, Inorg. Chem., 1963, 2 460; (d) J. Lucas and J.-P. Rannou, C. R. Acad. Sci. Ser. C., 1968, 266, 1056.

14. (a) B. E. Bursten, L F. Rhodes and R. J. Strittmatter, J. Am. Chem. Soc., 1989, 111, 2756; (b) B. E. Bursten, L F. Rhodes and R. J. Strittmatter, J. Am. Chem. Soc., 1989, 111, 2758; (c) N. Kaltsoyannis and B. E. Bursten, J. Organomet. Chem., 1997, 528, 19; (d) B. E. Bursten and R. J. Strittmatter, Angew. Chem. Int. Ed., 1991, 30, 1069; (e) N. Kaltsoyannis, J. Chem. Soc. Dalton. Trans., 1997, 1.

15. (a) I. Kirker and N. Kaltsoyannis, Dalton Trans., 2011, 40, 124; (b) N. Kaltsoyannis, Inorg. Chem., 2013, 52, 3407.

16. B. Kanellakopulos, E. Dornberger and F. Baumgartner, Inorg. Chem. Nucl. Lett., 1974, 10, 155.

17. T. M. Klapötke and A. Schulz, Polyhedron, 1997, 16, 989.

18. G. Ionova, C. Madic and R. Guillamont, Polyhedron, 1998, 17, 1991.

19. (a) J. H. Burns, W. H. Baldwin and F. H. Fink, Inorg. Chem., 1974, 13, 1916; (b) C. Wong, T. Lee and Y. Lee, Acta Crystallogr., Sect. B, 1969, 25, 2580.

20. T. J. Marks and W. A. Wachter, J. Am. Chem. Soc., 1976, 98, 703.

21. G. Kalina, T. J. Marks and W. A. Wachter, J. Am. Chem. Soc., 1977, 99, 3877.

22. J. W. Bruno, D. G. Kalina, E. A. Mintz and T. J. Marks, J. Am. Chem. Soc., 1982, 104, 1860.

23. P. C. Blake, M. F. Lappert, J. L. Atwood and H. Zhang, J. Chem. Soc., Chem. Commun., 1986, 1148.

24. P. C. Blake, M. F. Lappert, R. G. Taylor, J. L. Atwood and H. Zhang, Inorg. Chim. Acta, 1987, 139, 13.

25. P. C. Blake, N. M. Edelstein, P. B. Hitchcock, W. K. Kot, M. F. Lappert, G. V. Shalimoff and S. Tian, J. Organomet. Chem., 2001, 636, 124.

26. R. R. Langeslay, M. E. Fieser, J. W. Ziller, F. Furche and W. J. Evans, Chem. Sci., 2015, 6, 517. 
27. W. K. Kot, G. V. Shalimoff, N. M. Edelstein, M. A. Edelman and M. F. Lappert, J. Amvi Ghempnline Soc., 1988, 110, 986.

28. P. M. Boeerrigter, E. J. Baerends and J. G. Snijders, Chem. Phys., 1988, 122, 357.

29. W. K. Kot, PhD Thesis, University of California, Berkeley, 1991.

30. J. R. Walensky, R. L. Martin, J. W. Ziller and W. J. Evans, Inorg. Chem., 2010, 49, 10007.

31. N. A. Siladke, C. L. Webster, J. R. Walensky, M. K. Takase, J. W. Ziller, D. J. Grant, L. Gagliardi and W. J. Evans, Organometallics, 2013, 32, 6522.

32. R. R. Langeslay, M. E. Fieser, J. W. Ziller, F. Furch and W. J. Evans, J. Am. Chem. Soc., 2016, 138, 4036.

33. J. S. Parry, F. G. N. Cloke, S. J. Coles and M. B. Hursthouse, J. Am. Chem. Soc., 1999, 121, 6867.

34. M. R. MacDonald, M. E. Fieser, J. E. Bates, J. W. Ziller, F. Furche and W. J. Evans, J. Am. Chem. Soc., 2013, 135, 13310.

35. Q.-Y. Wu, J.-H. Lan, C.-Z. Wang, Z.-P. Cheng, Z.-F. Chai, J. K. Gibson and W.-Q. Shi, Dalton Trans., 2016, 45, 3102.

36. G. Erker, T. Mühlenbernd, R. Benn and A. Rufińska, Organometallics, 1986, 5, 402.

37. G. M. Smith, H. Suzuki, D. C. Sonnenberger, V. W. Day and T. J. Marks, Organometallics, 1986, 5, 549.

38. (a) O. J. Scherer, B. Werner, G. Heckmann and G. Wolmershäuser, Angew. Chem. Int. Ed., 1991, 30, 553; (b) O. J. Scherer, J. Schulze and G. Wolmershäuser, J. Organomet. Chem., 1994, 484, C5.

39. (a) I. Korobkov, S. Gambarotta and G. P. A. Yap, Angew. Chem. Int. Ed., 2003, 42, 814; (b) I. Korobkov, S. Gambarotta and G. P. A. Yap, Angew. Chem. Int. Ed., 2003, 42, 4958; (c) I. Korobkov and S. Gambarotta, Organometallics, 2004, 23, 5379; (d) I. Korobkov, A. Arunachalampillai and S. Gambarotta, Organometallics, 2004, 23, 6248; (e) A. Arunachalampillai, S. Gambarotta and I. Korobkov, Organometallics, 2005, 24, 1996; (f) A. Arunachalampillai, P. Crewsdon, I. Korobkov and S. Gambarotta, Organometallics, 2006, 25, 3856; (g) I. Korobkov, B. Vidjayacoumar, S. I. Gorelesky, P. Billone and S. Gambarotta, Organometallics, 2010, $29,692$. 
40. (a) W. Ren, G. Zi and M. D. Walter, Organometallics, 2012, 31, 672; (b) W. Ren, H. Songw GiclZijnine and M. D. Walter, Dalton Trans., 2012, 41, 5965; (c) W. Ren, W. W. Lukens, G. Zi, L. Maron and M. D. Walter, Chem. Sci., 2013, 4, 1168; (d) B. Fang, W. Ren, G. Hou, G. Zi, D.-C. Fang, L. Maron and M. D. Walter, J. Am. Chem. Soc. 2014, 136, 17249; (e) B. Fang, L. Zhang, G. Hou, G. Zi, D.C. Fang and M. D. Walter, Chem. Sci., 2015, 6, 4897; (f) B. Fang, L. Zhang, G. Hou, G. Zi, D.-C. Fang and M. D. Walter, Organometallics, 2015, 34, 5669; (g) B. Fang, G. Hou, G. Zi, W. Ding and M. D. Walter, Organometallics, 2016, DOI:10.1021/acs.organomet.5b00945.

41. R. R. Langeslay, J. R. Walensky, J. W. Ziller and W. J. Evans, Inorg. Chem., 2014, 53, 8455.

42. (a) S. Fortier, N. Kaltsoyannis, G. Wu and T. W. Hayton, J. Am. Chem. Soc., 2011, 133, 14224;

(b) S. Fortier, J. L. Brown, N. Kaltsoyannis, G. Wu and T. W. Hayton, Inorg. Chem., 2012, 51, 1625.

43. (a) O. T. Summerscales, F. G. N. Cloke, P. B. Hitchcock, J. C. Green and N. Hazari, Science, 2006, 311, 829; (b) A. S. Frey, F. G. N. Cloke, P. B. Hitchcock, I. J. Day, J. C. Green and G. Aitken, J. Am. Chem. Soc., 2008, 130, 13816; (c) O. T. Summerscales, A. S. P. Frey, F. G. N. Cloke and P. B. Hitchcock, Chem. Commun., 2009, 198; (d) A. S. P. Frey, F. G. N. Cloke, M. P. Coles and P. B. Hitchcock, Chem. Eur. J., 2010, 16, 9446; (e) A. S. P. Frey, F. G. N. Cloke, M. P. Coles, L. Maron and T. Davin, Angew. Chem. Int. Ed., 2011, 50, 6881. (f) A. S. P. Frey, F. G. N. Cloke, P. B. Hitchcock and J. C. Green, New J. Chem., 2011, 35, 2022; (g) N. Tsoureas, O. T. Summerscales, F. G. N. Cloke and S. M. Roe, Organometallics, 2013, 32, 1353; (h) N. Tsoureas, L. Castro, A. F. R. Kilpatrick, F. G. N. Cloke and L. Maron, Chem. Sci., 2014, 5, 3777.

44. Z. E. Button, J. A. Higgins, M. Suvova, F. G. N. Cloke and S. M. Roe, Dalton Trans., 2015, 44, 2588.

45. (a) O. P. Lam, S. C. Bart, H. Kameo, F. W. Heinemann and K. Meyer, Chem. Commun., 2010, 46, 3137; (b) A-C. Schmidt, A. V. Nizovtsev, A. Scheurer, F. W. Heinemann and K. Meyer, Chem. Commun., 2012, 48, 8634; (c) V. Mougel, C. Camp, J. Pecaut, C. Coperet, L. Maron, C. E. Kefalidis and M. Mazzanti, Angew. Chem. Int. Ed., 2012, 51, 12280.

46. R. J. Kahan, F. G. N. Cloke, S. M. Roe and F. Nief, New J. Chem., 2015, 39, 7602. 
47. A. Formanuik, F. Ortu, R. Beekmeyer, A. Kerridge, R. W. Adams and D. P. Mills, Daltoniframs.online 2016, 45, 2390.

48. (a) F. H. Stephens, PhD Thesis, Massachusetts Institute of Technology, Cambridge, 2004; (b)

D. Patel, F. Tuna, E. J. L. McInnes, W. Lewis, A. J. Blake and S. T. Liddle, Angew. Chem. Int. Ed., 2013, 52, 13334; (c) B. M. Gardner, F. Tuna, E. J. L. Mclnnes, J. McMaster, W. Lewis, A. J. Blake and S. T. Liddle, Angew. Chem. Int. Ed., 2015, 54, 7068.

49. I. M. Osadchenko and A. P. Tomilov, Russ. J. Appl. Chem., 2006, 79, 2033. 


\section{Table of contents}

In this Perspective article the synthesis, physical studies and reactivity of molecular Th(III) and Th(II) complexes are reviewed.

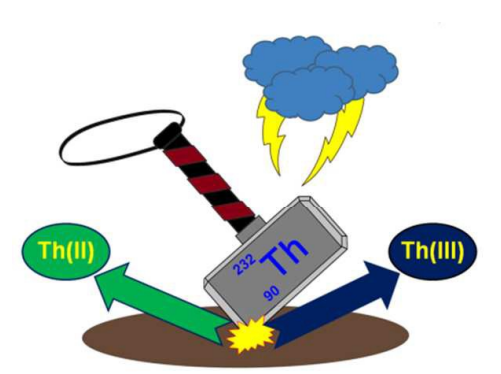

